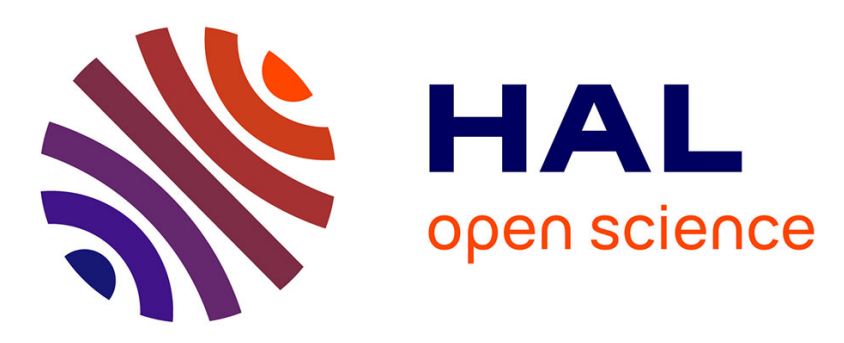

\title{
Gas-phase interactions of organotin compounds with glycine
}

\author{
Latifa Latrous, Jeanine Tortajada, Violette Haldys, Emmanuelle Léon, \\ Catarina Correia, Jean-Yves Salpin
}

\section{- To cite this version:}

Latifa Latrous, Jeanine Tortajada, Violette Haldys, Emmanuelle Léon, Catarina Correia, et al.. Gasphase interactions of organotin compounds with glycine. Journal of Mass Spectrometry, 2013, 48 (7), pp.795-806. 10.1002/jms.3223 . hal-00912483

\section{HAL Id: hal-00912483 https://hal.science/hal-00912483}

Submitted on 5 Oct 2018

HAL is a multi-disciplinary open access archive for the deposit and dissemination of scientific research documents, whether they are published or not. The documents may come from teaching and research institutions in France or abroad, or from public or private research centers.
L'archive ouverte pluridisciplinaire $\mathbf{H A L}$, est destinée au dépôt et à la diffusion de documents scientifiques de niveau recherche, publiés ou non, émanant des établissements d'enseignement et de recherche français ou étrangers, des laboratoires publics ou privés. 


\section{Gas-phase interactions of organotin compounds with glycine}

Latifa Latrous $^{1^{*}}$, Jeanine Tortajada ${ }^{2,3}$, Violette Haldys ${ }^{2,3}$, Emmanuelle Léon ${ }^{2,3}$, Catarina Correia $^{2,3}$ and Jean-Yves Salpin ${ }^{2,3 *}$

${ }^{1}$ Laboratoire de Chimie-Analytique et Electrochimie - Département de Chimie - Faculté des Sciences de Tunis - Campus Universitaire - 2092 El Manar - Tunis - TUNISIA

${ }^{2}$ Université d'Evry Val d'Essonne - Laboratoire Analyse et Modélisation pour la Biologie et l'Environnement Bâtiment Maupertuis - Université d'Evry Val d'Essonne - Boulevard François Mitterrand - 91025 Evry; FRANCE

${ }^{3}$ CNRS - UMR 8587

Number of pages (including 1 Table, 4 Figures and 3 schemes): 37

Corresponding author:

\section{Latifa Latrous}

Tel: 21697348880 Fax: 21671873948

e-mail : latrous_latifa@yahoo.fr 


\section{Abstract}

Gas-phase interactions of organotins with glycine have been studied by combining mass spectrometry experiments and quantum calculations. Positive-ion electrospray spectra show that the interaction of di- and tri-organotins with glycine results in the formation of $\left[(\mathrm{R})_{2} \mathrm{Sn}(\mathrm{Gly})-\mathrm{H}\right]^{+}$and $\left[(\mathrm{R})_{3} \mathrm{Sn}(\mathrm{Gly})\right]^{+}$ions, respectively. Di-organotin complexes appear much more reactive than those involving tri-organotins. (MS/MS) spectra of the $\left[(\mathrm{R})_{3} \mathrm{Sn}(\mathrm{Gly})\right]^{+}$ions are indeed simple and only show elimination of intact glycine, generating the $\left[(\mathrm{R})_{3} \mathrm{Sn}\right]^{+}$ carbocation. On the other hand, MS/MS spectra of $\left[(\mathrm{R})_{2} \mathrm{Sn}(\mathrm{Gly})-\mathrm{H}\right]^{+}$complexes are characterized by numerous fragmentation processes. Six of them, associated with elimination of $\mathrm{H}_{2} \mathrm{O}, \mathrm{CO}, \mathrm{H}_{2} \mathrm{O}+\mathrm{CO}$ and formation of $\left[(\mathrm{R})_{2} \mathrm{SnOH}\right]^{+}(-57 \mathrm{u}),\left[(\mathrm{R})_{2} \mathrm{SnNH}_{2}\right]^{+}(-58 \mathrm{u})$ and $\left[(\mathrm{R})_{2} \mathrm{SnH}\right]^{+}(-73 \mathrm{u})$ are systematically observed. Use of labeled glycines notably concludes that the hydrogen atoms eliminated in water and $\mathrm{H}_{2} \mathrm{O}+\mathrm{CO}$ are labile hydrogens. A similar conclusion can be made for hydrogens of $\left[\left(\mathrm{R}_{2}\right) \mathrm{SnOH}\right]^{+}$and $\left[\left(\mathrm{R}_{2}\right) \mathrm{SnNH}_{2}\right]^{+}$ions. Interestingly, formation $\left[(\mathrm{R})_{2} \mathrm{SnH}\right]^{+}$ions is characterized by a migration of one the $\alpha$ hydrogen of glycine onto the metallic center. Finally, several dissociation routes are observed and are characteristic of a given organic substituent.

Calculations indicated that the interaction between organotins and glycine is mostly electrostatic. For $\left[(\mathrm{R})_{2} \mathrm{Sn}(\mathrm{Gly})-\mathrm{H}\right]^{+}$complexes, a preferable bidentate interaction of the type $\eta^{2}-\mathbf{O}, \mathbf{N H 2}$ is observed, similar to that encountered for other metal ions. $\left[(\mathrm{R})_{3} \mathrm{Sn}\right]^{+}$ions strongly stabilize the zwitterionic form of glycine, which is practically degenerate with respect to neutral glycine. In addition, the interconversion between both forms is almost barrierless. Suitable mechanisms for these fragmentations processes are proposed in order to account for the most relevant fragmentation processes. 


\section{Introduction}

Organotin compounds (OTC) have been discovered 150 years ago and nowadays more than 800 different organotins are known. Organotin (IV) compounds are characterized by the presence of at least one covalent C-Sn bond. The compounds contain tetravalent Sn centres and are classified as mono-, di-, tri- and tetra-organotin (IV)s, depending on the number of alkyl (R) or aryl (Ar) moieties. The anionic partner, when present, is usually chloride or fluoride atoms, or oxide, hydroxide, carboxylate or thiolate group. Most of these compounds are of anthropogenic origin except methyltins, which can also be produced by biomethylation. ${ }^{1}$

Nowadays, the main application of OTC's still corresponds to the use of mono/dialkyltin derivatives as heat and light stabilizer additives in PVC processing ${ }^{2}$. Tri-organotins have been also widely used. Their biocidal properties were discovered in the late 1950 's ${ }^{3}$ and were first applied as an ingredient in timber preservatives. Further uses of tri-organotins (primarily tributyl, triphenyl and tricyclohexyltin compounds) included fungicide, miticide, molluscicides, nematocides, ovicides, rodent repellent, wood preservatives and antifouling paints toxic additives ${ }^{4}$.

The exponential increase of the industrial, agricultural and biological applications of the organotin (IV) compounds during the last 150 years has led to their accumulation in the environment and finally in biological systems. However, organotin compounds are generally very toxic, even at low concentrations. The speciation of organotins in the biological systems has revealed that the biological activity of these compounds may be due to the presence of easily hydrolysable groups (easily dissociable chelating ligands) yielding the intermediates, such as $\mathrm{R}_{\mathrm{n}} \mathrm{Sn}^{(4-\mathrm{n})+}(\mathrm{n}=2$ or 3 ) moieties, which may bind with DNA, ATPase and haemoglobins (histidine and cystine) ${ }^{5-8}$. During the last two decades, considerable efforts 
have been made to characterize model organotins compounds with ligands having hetero donor atoms $(\mathrm{O}, \mathrm{N}$ and /or $\mathrm{S}){ }^{9-15}$ and to study structure-activity correlations ${ }^{16-18}$.

A number of organotin derivatives have been shown to exhibit an efficient anticancer activity ${ }^{19,20}$. However, as for many drugs used in chemotherapy, they may have undesirable side effects. Therefore, understanding the interaction of organotin compounds with possible biological targets is highly desirable, and this has led to a growing interest in the studies dealing with their interactions with different naturally-occurring ligands, such as carbohydrates, nucleic acid derivatives, amino acids, and peptides ${ }^{21-25}$.

In spite of these efforts, the mechanism of action of these drugs in the living cell is not well understood. Amino acids, peptides and proteins are well-known as efficient biological metal ion binders; therefore their interaction with organotin cations may play an important role in the mechanism of the above-mentioned toxic/antitumor effect. In order to clarify the alkyltin/ and phenyltin/peptide interaction, various studies have been investigated using potentiometry, ${ }^{1} \mathrm{H},{ }^{13} \mathrm{C}$ NMR and Mössbauer spectroscopic methods ${ }^{26-29}$. To the best of our knowledge, the interaction of OTCs with aminoacids or peptides by mass spectrometry has not been explored so far, though such gas-phase studies could provide useful insights about their intrinsic reactivity. In this paper, we report our systematic investigations on the interactions of aminoacids with OTC. In this respect, glycine represents the simplest model for such a theoretical and experimental investigation. Gas-phase organotin complexes with glycine were produced by ESI-MS. Tandem MS experiments were performed in order to probe the structure of the complexes generated in the gas phase. In order to rationalize our experimental findings, we also carried out computations using the B3LYP hybrid density functional. 


\section{Experimental}

\section{Mass spectrometry}

Electrospray ionization mass spectra were recorded on a QSTAR PULSAR i (Applied Biosystems/MDS Sciex) hybrid instrument (QqTOF) fitted with a "nanospray" source to minimize transfer line contamination. Standard stock solutions of $10^{-2} \mathrm{~mol} \mathrm{~L}^{-1}$ were first prepared in methanol and stored at $4^{\circ} \mathrm{C}$. Several $\mu \mathrm{L}$ of glycine/OTC mixtures $\left(510^{-4} \mathrm{M} / 10^{-4} \mathrm{M}\right.$ in $50 / 50$ methanol/milli-Q water were then nanosprayed $\left(20-50 \mathrm{~nL} \mathrm{~min}^{-1}\right)$ using borosilicate emitters (Proxeon). Samples were ionized using a $900 \mathrm{~V}$ nanospray needle voltage and the lowest possible nebulizing gas pressure (tens of millibars). The declustering potential DP (also referred to as "cone voltage" in other devices), defined as the difference in potentials between the orifice plate and the skimmer (grounded), was varied from 0 to $120 \mathrm{~V}$ for optimization purpose and was finally set to $50 \mathrm{~V}$ to record both MS and MS/MS spectra. For MS/MS spectra, ions of interest were mass-selected by using quadrupole Q1, and allowed to collide with nitrogen gas at various collision energies ranging from 8 to $25 \mathrm{eV}$ in the laboratory frame (the collision energy is given by the difference of potentials between Q0 and Q2) with the resulting fragment ions separated by the time-of-flight (TOF) analyser after orthogonal injection. The CAD parameter, which roughly controls the amount of $\mathrm{N}_{2}$ introduced into Q2, was set to its minimum value in order to limit multiple ion-molecule collisions. Setting this parameter to 1 during MS/MS experiments resulted in pressure values of $1-210^{-5}$ Torr as measured by the ion gauge located at vicinity but outside the collision cell. It has been reported ${ }^{30}$ that the pressure inside the collision cell is in fact the order of 10 mTorr. At this pressure and given the dimension of the LINAC collision cell (about 22 centimeters long), one can find that the mean free path for a $\mathrm{N}_{2}$ molecule is about $5 \mathrm{~mm}$. So, at this pressure not only $\mathrm{N}_{2}$ molecule but also complexes of interest (which have higher 
collision cross-sections) may undergo tens of collisions along their path through Q2. Note that this estimate is a lower limit since $\mathrm{N}_{2}$ also enters Q0 and Q1 for collisional focusing. Consequently, even with the minimum amount of $\mathrm{N}_{2}$ inside the collision cell, we are certainly under a multiple collision regime.

Unless otherwise noted, mass to charge ratios mentioned throughout this paper refer to as peaks which include the most abundant tin isotope $\left({ }^{120} \mathrm{Sn}\right)$. Glycine, methanol (HPLC grade), triphenyltin chloride ( $\mathrm{TPhTCl})$, tributyltin chloride $(\mathrm{TBTCl})$, dibutyltin dichloride $\left(\mathrm{DBTCl}_{2}\right.$; purity $\left.\geq 96 \%\right)$, diphenyltin dichloride $\left(\mathrm{DPhTCl}_{2}\right.$; purity $\left.\geq 93 \%\right)$ were purchased from Sigma-Aldrich (Saint-Quentin Fallavier, France), while dimethyltin dichloride $\left(\mathrm{DMTCl}_{2}\right)$ and trimethyltin chloride (TMTCl) were purchased from Riedel de Haen (Seelze, Germany).

\section{Computational details}

Density functional theory (DFT) calculations were carried out using the B3LYP hybrid functional, as implemented in the Gaussian 03 suite of programs ${ }^{31}$. B3LYP combines the nonlocal correlation function of Lee et al. ${ }^{32}$, with the Becke's three-parameter non local hybrid exchange functional ${ }^{33}$. The different structures have been optimized with a dppolarized $6-31+G(d, p)$ basis set expansion, which includes polarization functions on all atoms. The Def2-SVP ${ }^{34}$ basis set and effective core potential was used to describe the tin atom. This approach implies a 28 -electron effective core potential. Consequently, 20 electrons are treated explicitly for the $\mathrm{Sn}^{2+}$ cation, resulting in rather expensive calculations, especially with n-Bu- and $\mathrm{Ph}$ - containing OTC. We chose this approach in order all the complexes to be computationally tractable at the same level of calculation. Harmonic vibrational frequencies were computed at the same level in order to estimate the corresponding zero-point vibrational energy (ZPVE) corrections (scaled by $0.986^{35}$ ) and to classify the stationary points of the 
potential energy surfaces (PES) either as local minima or transition states (TS). Intrinsic reaction coordinate (IRC) calculations were carried out to ascertain the connection between TS and local minima.

Further insight into the nature of bonding was gained by using the atoms-in-molecules approach. $^{36,37}$ For this purpose, we located bond critical points and calculated the charge density values associated with them so as to be able to compare bond strengths.

\section{Results and Discussion}

\section{Mass spectrometry}

\section{Gly/di-organotins}

A typical nano-electrospray spectrum obtained at $\mathrm{DP}=50 \mathrm{~V}$ for a $1: 5$ aqueous mixture of DMT/glycine is displayed in Figure 1a. Several types of ions are detected. Interaction between DMT and glycine gives rise exclusively to a singly charged complex of general formula $\left[\left(\mathrm{CH}_{3}\right)_{2} \mathrm{Sn}(\mathrm{Gly})-\mathrm{H}\right]^{+}$, detected at $m / z 223.97$ and associated with formal deprotonation of glycine. Consistently, studies performed in condensed phase have shown that interaction of diorganotins with glycine and Gly-Gly is accompanied by deprotonation of the ligand ${ }^{22-24}$. Tin-containing ions can be easily identified because of the specific isotopic distribution of this metal, resulting in characteristic isotopic profiles. Consequently, most of the ions detected in the 150-210 mass range include one tin atom and correspond (vide infra) to fragments arising from the initial complex. Note that the isotopic profiles also confirm the lack of any chloride atom. The two species detected at $m / z 205.97$ and 195.98 result from the loss of $\mathrm{H}_{2} \mathrm{O}$ and $\mathrm{CO}$ respectively while the other ions observed at $\mathrm{m} / \mathrm{z} 180.97,166.95$ and 150.96 certainly 
correspond to $\left[\left(\mathrm{CH}_{3}\right)_{2} \mathrm{SnOCH}_{3}\right]^{+},\left[\left(\mathrm{CH}_{3}\right)_{2} \mathrm{SnOH}\right]^{+}$and $\left[\left(\mathrm{CH}_{3}\right)_{2} \mathrm{SnH}\right]^{+}$, respectively. In addition a $\left[\left(\mathrm{CH}_{3}\right)_{2} \mathrm{SnOH} .\left(\mathrm{H}_{2} \mathrm{O}\right)\right]^{+}(\mathrm{m} / z$ 184.92) complex is also present. The protonated form of glycine [Gly] $\mathrm{H}^{+}$is detected at $\mathrm{m} / z, 76.05$ and the species at $\mathrm{m} / z, 98.03$ is attributed to [Gly] $\mathrm{Na}^{+}$. Similar spectra are obtained with both diphenyltin dichloride and dibutyltin dichloride, and are characterized by abundant formation of $\left[(\mathrm{R})_{2} \mathrm{Sn}(\mathrm{Gly})-\mathrm{H}\right]^{+}$complexes (see supporting information, Figure S1).

Globally, the electrospray spectra obtained with di-organotins are markedly simple given the numerous species that can be generated in condensed phase by hydrolysis. Organotins, which can indeed be considered as Lewis acids, display a strong tendency to hydrolysis in aqueous solutions and give rise to aquo, hydroxo or polynuclear complexes of various charge states over a wide $\mathrm{pH}$ range ${ }^{23,24}$. Only the complexes $\left[\left(\mathrm{CH}_{3}\right)_{2} \mathrm{SnOH}\right]^{+}$and $\left[\left(\mathrm{CH}_{3}\right)_{2} \mathrm{SnOH} .\left(\mathrm{H}_{2} \mathrm{O}\right)\right]^{+}$ detected at $\mathrm{m} / z, 166.95$ and 184.92 , respectively, may arise from the hydrolysis of the diorganotins. We did not detect any doubly charged complexes of the type $\left[(\mathrm{R})_{2} \mathrm{Sn}\left(\mathrm{H}_{2} \mathrm{O}\right)_{n}\right]^{2+}$ known to be formed in water ${ }^{23,24}$. However, these latter ones may be transiently generated and spontaneously dissociate to generate hydroxo species. Finally, we do not detect any polynuclear complexes, the isotopic distribution of tin-containing ions being systematically consistent with the presence of a single metallic center. No ions incorporating chloride are detected.

\section{Gly/tri-organotins}

The gas-phase reactivity observed with tri-organotin compounds is sensibly different as illustrated by Figure 1b. In addition to protonated and sodiated glycine, the mass spectrum is dominated by the intense $\left[(\mathrm{R})_{3} \mathrm{Sn}\right]^{+}$ion $\left(\mathrm{m} / \mathrm{z}\right.$ 164.97; $\left.\mathrm{R}=\mathrm{CH}_{3}\right)$, regardless of the nature of the 
organic substituent. Interaction with the amino acid only results in the formation of a complex of the type $\left[(\mathrm{R})_{3} \mathrm{SnGly}\right]^{+}\left(\mathrm{m} / \mathrm{z}, 240.00 ; \mathrm{R}=\mathrm{CH}_{3}\right)$ that may be viewed as the association of the former carbocation with neutral glycine. Such a system has also been studied in solution and in aqueous solutions at $\mathrm{pH} 7$, and there was little evidence of complex formation between $\mathrm{Me}_{3} \mathrm{Sn}(\mathrm{IV})^{+}$and glycine ${ }^{27}$.

The different nature of the complex observed when increasing the number of organic ligands suggests that the presence of a second chloride atom (di-organotins) may promote deprotonation of the amino acid. Again, no ions incorporating chloride are detected.

\section{MS/MS experiments}

To examine the unimolecular reactivity upon collision of the observed complexes, we have carried out a series of MS/MS experiments, and results are summarized in Table 1. MS/MS spectra have been recorded at DP $=50 \mathrm{~V}$, a value for which precursor ions are produced in sufficient abundances.

MS/MS spectra of the $\left[(\mathrm{R})_{3} \mathrm{SnGly}\right]^{+}$ions are remarkably simple as illustrated by Figure S2 (supporting information). A unique process is observed, namely elimination of intact glycine leading to the formation of the $\left[(\mathrm{R})_{3} \mathrm{Sn}\right]^{+}$carbocation. This fragmentation already occurs to a very large extent at low collision energy, suggesting that the interaction between the $\left[(\mathrm{R})_{3} \mathrm{Sn}\right]^{+}$ carbocation and glycine is very weak. Using collision energies as high as $35 \mathrm{eV}$ (laboratory frame) still does not induce additional fragmentation. This behavior is therefore similar to the unimolecular reactivity of alkali metal ions/glycine systems, as studied by threshold experiments ${ }^{38-41}$.

On the other hand, MS/MS spectra of the complexes obtained with the di-organotin compounds are much more informative, and are illustrated by Figure 2 for dimethyl tin 
dichloride. Upon collision, the three $\left[(\mathrm{R})_{2} \mathrm{Sn}(\mathrm{Gly})-\mathrm{H}\right]^{+}$complexes share several fragmentation processes as described by Scheme 1. Six fragment ions are systematically observed, associated with elimination of $\mathrm{H}_{2} \mathrm{O}, \mathrm{CO}$, and losses of 46, 57, 58 and 73 Daltons, which correspond to $\mathrm{m} / \mathrm{z}$ 205.96, 195.98, 177.97, 166.96, 150.96, 134.94 ions in Figure 2a, respectively. Dehydration is particularly intense with DMT while its abundance significantly decreases with the bulkier organic ligands ( $\mathrm{n}-\mathrm{Bu}$ and $\mathrm{Ph}$ ).

In order to get further insights about the mechanisms leading to the various fragment ions, we used labeled glycine, namely $1{ }^{13} \mathrm{C}$-glycine and 2,2-D - glycine. The mass shifts observed for the six common fragmentations are summarized in Table 1. From this table one can first conclude that the deprotonation of glycine implies a labile proton since the mass to charge ratio of the precursor ion is shifted by 2 mass units when using 2,2- $\mathrm{D}_{2}$-glycine. Table 1 also shows that the loss of 28 Daltons systematically involves the carbonyl group of the glycine. A similar conclusion can be drawn for the loss of 46 Daltons. In addition, results obtained with 2,2- $\mathrm{D}_{2}$-glycine indicate that the hydrogen atoms eliminated in both water and the $46 \mathrm{u}$ moiety are labile hydrogens. The unimolecular reactivity upon collision of these complexes therefore appears somewhat similar to that observed with other metals cations such as $\mathrm{Ni}(\mathrm{I}), \mathrm{Cu}(\mathrm{I})$, $\mathrm{Zn}(\mathrm{II})$ and $\mathrm{Pb}(\mathrm{II})$. For example, glycine dehydration has also been experimentally observed for $[\mathrm{Ni}(\mathrm{Gly})]^{+}{ }^{42},[\mathrm{Cu}(\mathrm{Gly})]^{+}{ }^{43}$ and $[\mathrm{Pb}(\mathrm{Gly})-\mathrm{H}]^{+}$complexes ${ }^{44}$. Elimination of carbon monoxide is also characteristic of the $[\mathrm{Ni}(\mathrm{Gly})]^{+}{ }^{42},[\mathrm{Zn}(\mathrm{Gly})-\mathrm{H}]^{+}{ }^{45-47}$ and $[\mathrm{Pb}(\mathrm{Gly})-\mathrm{H}]^{+}$ complexes ${ }^{44}$ while elimination of 46 Daltons is observed regardless of the nature of the ionizing agent. The elemental composition associated with the latter loss is $\left[\mathrm{C}, \mathrm{H}_{2}, \mathrm{O}_{2}\right]$ and may therefore correspond either to formic acid $(\mathrm{HCOOH})$, dihydroxycarbene $\left(\mathrm{C}(\mathrm{OH})_{2}\right)$, combined elimination of $\mathrm{H}_{2}+\mathrm{CO}_{2}$, or $\mathrm{H}_{2} \mathrm{O}+\mathrm{CO}$. However, it is worth mentioning that previous experimental and theoretical studies both on protonated glycine ${ }^{48}$ and $\mathrm{Cu}^{+} /$glycine ${ }^{43}$ demonstrated that this process corresponded exclusively to sequential elimination of water 
and carbon monoxide. Such a fragmentation pattern may therefore be reasonably assumed in the case of organotins since losses of water and carbon monoxide are indeed observed, and because our data deduced from labeled glycines are in agreement with the results obtained by H/D exchange for the $[\mathrm{Cu}(\mathrm{Gly})]^{+43}$ and $[\mathrm{Zn}(\mathrm{gGly})-\mathrm{H}]^{+45-47}$ complexes. However, unlike the latter species, elimination of carbon dioxide is not observed.

Other significant fragmentations are observed. These are elimination of 57 and $73 \mathrm{u}$ which are associated with the formation of $\left[(\mathrm{R})_{2} \mathrm{SnOH}\right]^{+}$and $\left[(\mathrm{R})_{2} \mathrm{SnH}\right]^{+}$, respectively. Interestingly, similar processes have been observed for the $[\mathrm{Zn}(\mathrm{Gly})-\mathrm{H}]^{+45,46}$ and $[\mathrm{Pb}(\mathrm{Gly})-\mathrm{H}]^{+}{ }^{44}$. Formation of $[\mathrm{ZnOH}]^{+}$and $[\mathrm{ZnH}]^{+}$have been attributed to loss of $\mathrm{CO}$ and $\mathrm{CO}_{2}$, respectively, followed by elimination of $\mathrm{CH}_{2} \mathrm{NH}$. A similar mechanism has been proposed for the formation of lead hydroxide. As for $[\mathrm{PbH}]^{+}$, its formation was attributed to three consecutive losses of $\mathrm{H}_{2} \mathrm{O}, \mathrm{CO}$ and $\mathrm{HCN}^{44}$.

Again, use of labeled glycines (Table 1) appears very informative. Formation of $\left[(\mathrm{R})_{2} \mathrm{SnH}\right]^{+}$ species is systematically characterized by a migration of one the $\mathrm{C}_{\alpha}$ hydrogens of glycine onto the metallic center, while the $\left[(\mathrm{R})_{2} \mathrm{SnOH}\right]^{+}$ion only involves labile hydrogens. These experiments are in agreement with data deduced from $\mathrm{H} / \mathrm{D}$ exchange for the $[\mathrm{Zn}(\mathrm{gly})-\mathrm{H}]^{+}$ complex ${ }^{45,46}$. Finally, the formation of $\left[(\mathrm{R})_{2} \mathrm{SnNH}_{2}\right]^{+}$appears specific of organotins and again only involves labile hydrogens (Table 1).

All the dissociation processes mentioned so far are observed for the three di-organotin compounds studied. However, as depicted in scheme 1, several dissociation routes are characteristic of a given organic substituent. For example, elimination of intact glycine $(75 \mathrm{u})$ from the $\left[(\mathrm{R})_{2} \mathrm{Sn}(\mathrm{Gly})-\mathrm{H}\right]^{+}$complex is specifically observed for $\mathrm{R}=\mathrm{n}-\mathrm{Bu}$, and gives rise to an abundant $[(\mathrm{R}) \operatorname{Sn}(\mathrm{R}-\mathrm{H})]^{+}$ion $(\mathrm{m} / \mathrm{z} 233$, see Figure $\mathrm{S} 3)$. This fragmentation is therefore characterized by the abstraction of a proton of one of the two butyl groups. This species 
further expels a $(\mathrm{R}-\mathrm{H})$ moiety which may correspond to a butene molecule, to generate the $[(\mathrm{R}) \mathrm{Sn}]^{+}$ion. Note that this latter ion is also generated by elimination of $\mathrm{RH}$ from the $\left[(\mathrm{R})_{2} \mathrm{SnH}\right]^{+}$complex. Again, in the particular case of the DBT, loss of a $(\mathrm{R}-\mathrm{H})$ neutral moiety is also observed from $[(\mathrm{n}-\mathrm{Bu}) \mathrm{Sn}]^{+}$and $\left[(\mathrm{n}-\mathrm{Bu})_{2} \mathrm{SnH}\right]^{+}$ions, leading to $[\mathrm{SnH}]^{+}$and $[(\mathrm{n}-$ $\left.\mathrm{Bu}) \mathrm{SnH}_{2}\right]^{+}$, respectively. Consequently, the elimination of a $(\mathrm{R}-\mathrm{H})$ molecule with $\mathrm{R}=\mathrm{n}-\mathrm{Bu}$ implies the insertion of the metal into a $\mathrm{C}-\mathrm{H}$ bond. Such processes have been already observed for other metals such as $\mathrm{Ni}, \mathrm{Fe}, \mathrm{Pt}$ or $\mathrm{Co}^{49-52}$.

\section{Computational study}

In order to complete our experimental study and to gain some insights about the structures of the complexes observed in the gas phase, we have also carried out theoretical calculations.

Di-organotins/amino acids systems have been studied in solution by potentiometry (determination of formation constants) and by different experimental techniques such as Mössbauer, NMR and UV spectroscopies. From these studies, it was deduced that these complexes undergo deprotonation for $\mathrm{pH} \geq 3-4$. Given the $\mathrm{pH}$ of our solutions (typically 5.5), it is therefore not surprising to observe complexes with deprotonated glycine in the gas phase. Deprotonation in solution may be attributed either to i) the deprotonation of a metal bound water molecule forming hydroxo mixed-ligand complexes, or ii) to the metal-promoted deprotonation of the amino acid. In this latter case, solution-phase data also suggested the deprotonation of the carboxylic group which then interacts with the metallic center ${ }^{22,23}$. Note however that deprotonation of the amino group has also been proposed ${ }^{53}$. Consequently, both deprotonation sites have been considered in our theoretical survey. For the sake of comparison, initial deprotonation of the $\alpha$ methylene group has also been considered, even 
though, based on our experimental findings, such a deprotonation does not occur. Finally, deprotonation of the organic ligands has also been considered.

The various structures were labelled according to the following convention. The interacting centers (e.g. $\mathrm{O}, \mathrm{NH} 2, \mathrm{OH} \ldots$ ) are specified after the name of the organotin, augmented by a number to differentiate the different conformers of a given binding scheme.

It is now well established that the zwitterionic form of glycine is not stable in the gas phase. On the other hand, the isoelectric point (pI) of glycine being 5.97, in aqueous solution, glycine should be primarily in its zwitterionic form in pH 4-8 range. Consequently, preformed eomplexes in solution between metal ions and zwitterionic glycine may be directly transferred in the gas phase by ESI. Furthermore, many theoretical studies have shown $52-64$ that zwitterionic glycine can be strongly stabilized through the interaction with divalent metal ions, so that this particular conformation, usually named salt bridge (SB), is generally the global minimum, and can play a key role in the unimolecular reactivity of $\mathrm{M} 2+$ /glycine eomplexes 60. Consequently, we also considered complexation onto zwitterionic forms. These structures are presently labelled as "ZW".

The various local minima found for the $\left[\left(\mathrm{CH}_{3}\right)_{2} \mathrm{Sn}(\mathrm{Gly})-\mathrm{H}\right]^{+}$complex are displayed in Figure 3, while geometries obtained for the complexes formed with DBT and DPhT are given in Figures S5 and S6, respectively. Computational data associated with the various structures are also provided in the supporting information. Examination of Figure 3 and Table $1 \mathrm{~S}$ indicates that the most stable forms are globally associated with deprotonation of the carboxylic group. This was rather expected since the carboxylic group is the most acidic group of glycine in the gas phase ${ }^{54}$. On the other hand, the N-deprotonated form DMT- $\eta^{2}-\mathbf{N H , O - 1}$ is located only $14.5 \mathrm{~kJ} / \mathrm{mol}$ above the global minimum. Consequently, the interaction with the $\left(\mathrm{CH}_{3}\right)_{2} \mathrm{Sn}^{2+}$ considerably reduces the relative acidity of the various deprotonation sites of glycine, since 
the amino group is more than $200 \mathrm{~kJ} / \mathrm{mol}$ less acidic than the carboxylic group for neutral glycine ${ }^{54}$. Two kinds of O-deprotonated forms were located. The first one implies a bidentate interaction with the carboxylate group (DMT- $\eta^{2}-\mathbf{O}, \mathbf{O}-\mathbf{n}$ structures). DMT- $\eta^{2}-\mathbf{O}, \mathbf{0}-\mathbf{1}$ formally corresponds to the interaction of the $\left(\mathrm{CH}_{3}\right)_{2} \mathrm{Sn}^{2+}$ moiety with the most stable neutral form of glycine ${ }^{55}$, which is characterized by a $\mathrm{C}_{\mathrm{s}}$ symmetry and two long-range $\mathrm{NH} \ldots \mathrm{O}=\mathrm{C}$ interactions (Structure GlyA; Figure S9), and presently deprotonated. The distances between the metal cation and the two oxygens are rather similar as already observed for $[\mathrm{Zn}(\mathrm{Gly})-\mathrm{H}]^{+}$ 45 and $[\mathrm{Pb}(\mathrm{Gly})-\mathrm{H}]^{+44}$ complexes. Note however that the computed M-O distances are longer for $\mathrm{Sn}\left(\mathrm{CH}_{3}\right)_{2}$ than for $\mathrm{Zn}$, thus suggesting a weaker electrostatic interaction. In order to have further insights about the metal ion-glycine bond nature within the $\left[\left(\mathrm{CH}_{3}\right)_{2} \mathrm{Sn}(\mathrm{Gly})-\mathrm{H}\right]^{+}$ structures, we have carried out a natural population analysis (NPA) at the B3LYP/6$31+\mathrm{G}(\mathrm{d}, \mathrm{p})$ level by means of the NBO program ${ }^{56}$ for the most stable structures investigated and for the $\left[\left(\mathrm{CH}_{3}\right)_{2} \mathrm{Sn}\right]^{2+}$ species. NBO calculations indicate that the absolute value of the charge of Sn is of 2.12 for the dication, while the charge of the metallic center within the two most stable forms is of 2.03-2.05. The charge transfer is therefore very minor and the interaction seems mostly ionic. We also performed a Bader topological analysis for the most stable forms of the complexes (see Figure S10 for typical examples). This topological analysis shows that the electron density at the O-Sn and/or N-Sn bond critical points (BCPs) are small (0.06-0.09 $\left.\mathrm{e} \mathrm{au}^{-3}\right)$, and finds positive values for the Laplacian of the charge density in the region between the two interacting subunits, as is typical of conventional ionic linkages. As a result of the ionic bonding, polarization effects are quite important. The $(\mathrm{R})_{2} \mathrm{Sn}^{2+}$ moiety causes a significant reorganization of the glycine charge density, resulting in the activation of several bonds. In the case of the DMT$\eta^{2}$-O,O-1 structure, the two C-O bonds lengthen by $\sim 0.023-0.030 \AA$ upon complexation, with respect to anionic glycine. On the other hand, the C-C bond is shortened by $0.046 \AA$. The electron density at the associated BCPs varies accordingly as they decreases by $0.020-0.025$ 
$\mathrm{e} \mathrm{au}^{-3}$ for $\mathrm{C}-\mathrm{O}$ bonds and increases by 0.15 for the C-C bond. Generally, the $(\mathrm{R})_{2} \mathrm{Sn}^{2+}$ moiety induces withdrawal of electrons from the atom or atoms coordinated to it, thus weakening the adjacent bond(s) and reinforcing the next one(s). Interestingly, interaction with the metal results in the weakening of the two long-range $\mathrm{NH} \ldots \mathrm{O}=\mathrm{C}$ interactions, as attested by the NH...O distances which are of $2.63 \AA$ in the deprotonated form and $2.94 \AA$ in DMT- $\boldsymbol{\eta}^{2}-\mathbf{O}, \mathbf{O}$ 1. Consequently, interaction with di-organotins should reduce the rotational barrier along the C-N bond.

Comparison of the three DMT- $\eta^{2}-\mathbf{O}, \mathbf{O}-\mathbf{n}$ forms also indicate that the relative orientation of the methyl groups have practically no influence onto the energy, and that the two long-range $\mathrm{NH} . . \mathrm{O}=\mathrm{C}$ interactions, if actually present, only provide a weak stabilization- Note that these interactions do not exist according to the natmral population analysis.

The global minimum obtained is denoted DMT- $\eta^{\mathbf{2}}-\mathbf{O}, \mathbf{N H 2 - 1}$ and corresponds to the metal cation interacting with the nitrogen atom and with the carboxylate group. This structure is almost planar (OCCN dihedral angle of $18.1^{\circ}$ ) and implies the formation of a five-membered ring. This binding scheme implies the distortion of the most stable form of neutral glycine (GlyA, Figure S9), since the pyramidalization of the amino group is indeed reversed, in order to allow both $\mathrm{O}$ and $\mathrm{N}$ atoms to interact with the metallic center. However, the strong binding interaction thus obtained overcomes the distortion energy. This particular conformation was also found to be the most stable for the two alkali metals $\mathrm{Li}^{+}$and $\mathrm{Na}^{+} 38,57-60$ as well as for transition metal ions such as $\mathrm{Cu}^{+55,57,58,61,62}, \mathrm{Ni}^{+42,57}, \mathrm{Ag}^{+58} 62$ or $\mathrm{Co}^{+63}$. On the other hand, it does not correspond to the global minimum for the $[\mathrm{Pb}(\mathrm{Gly})-\mathrm{H}]^{+}$ions ${ }^{44}$, N-deprotonation being favored in the latter case.

The most stable form arising from deprotonation of the methylene group, DMT- $\eta^{2}-\mathbf{O}, \mathbf{N H 2}-\mathbf{2}$, shares the same binding scheme as the global minimum but is $46.6 \mathrm{~kJ} / \mathrm{mol}$ less stable. Figure 
3 shows that the Sn-O distance (2.047 $\AA$ ) is longer than for DMT- $\eta^{2}-\mathbf{O}, \mathbf{N H 2 - 1}$. This can be attributed to the $\mathrm{sp}^{2}$ hybridization of the $\mathrm{C}(\alpha)$ atom, which result in a smaller CCO bond angle, and in a more constrained geometry. As mentioned previously, structures arising from $\mathrm{N}$-deprotonation are less favored, even if the tin significantly increases the acidity of the amino group. Examination of the various $\mathrm{N}$-deprotonated forms shows that a strong stabilization is achieved only if the metal interacts with the carbonyl group. Structures for which the metal interacts both with the nitrogen and the hydroxyl group (DMT- $\left.\eta^{2}-\mathbf{N H , O H}-\mathbf{n}\right)$ are less stable. The difference between $\eta^{2}-\mathrm{NH}, \mathrm{O}$ and $\eta^{2}-\mathrm{NH}, \mathrm{OH}$ structures mainly arises from the smaller electrostatic interaction in $\eta^{2}-\mathrm{NH}, \mathrm{OH}$, the hydroxyl oxygen being less basic than the carbonyl one. Additional stabilization is also provided by $\mathrm{OH}^{\cdots} \mathrm{O}=\mathrm{C}$ intramolecular hydrogen bond (DMT- $\eta^{2}$-NH,OH-1). We also obtained several monodentate forms, in which the metal solely interacts with the deprotonated nitrogen. Comparison of DMT- $\boldsymbol{\eta}^{\mathbf{1}}$-NH-1 with DMT- $\eta^{1}-\mathbf{N H , O - 1}$ shows that the stabilization provided by the interaction with the carbonyl group can be roughly estimated to c.a. $70 \mathrm{~kJ} / \mathrm{mol}$.

As mentioned previously, we also considered deprotonation of the methyl group instead of glycine. When one of the methyl groups is deprotonated, the metallic center then adopts a tetrahedral configuration. The interaction with glycine is monodentate when only the carboxylic group is involved (DMT- $\boldsymbol{\eta}^{\mathbf{1}}-\mathbf{O}-\mathbf{1}$ or DMT- $\boldsymbol{\eta}^{\mathbf{1}} \mathbf{- O}-\mathbf{2}$; Figure 3). A bidentate interaction is found when both the carbonyl group and the amino group interact (DMT- $\boldsymbol{\eta}^{\mathbf{1}}-\mathbf{O}, \mathbf{N H 2}-\mathbf{3}$ ). Globally, these forms are about $170 \mathrm{~kJ} / \mathrm{mol}$ above the global minimum. Consequently, deprotonation of the methyl group is less favorable than deprotonation of glycine.

Since $\left[(\mathrm{R})_{2} \mathrm{SnH}\right]^{+}$ions are generated under CID conditions, we also considered structures in which a hydrogen atom from a methylene group (as proven by deuterium labelling experiments) was transferred onto the metal, after deprotonation of either $\mathrm{NH}_{2}$ of $\mathrm{COOH}$ 
groups. Such forms indeed correspond to the global minima for the $[\mathrm{Zn}(\mathrm{Gly}-\mathrm{H})]^{+}$complex ${ }^{45}$. These structures, denoted as INT1 and INT2, are displayed in Figure 3. They are indeed local minima on the potential energy surface, but unlike what is observed for zinc, do not correspond to the most stable structures. These structures correspond to monodentate forms located 57-65 kJ/mol above DMT- $\eta^{2}-\mathbf{O}, \mathbf{N H 2}-1$. They are possible intermediates for the fragmentation process leading to $\left[\left(\mathrm{CH}_{3}\right)_{2} \mathrm{SnH}\right]^{+}$. Finally, we also located a zwitterionic species, DMT- $\boldsymbol{\eta}^{\mathbf{1}} \mathbf{- Z W}-\mathbf{1}$, which is a N-deprotonated structure with the metal interacting with the carboxylic group. This form is located $393.6 \mathrm{~kJ} / \mathrm{mol}$ above the global minimum. Consequently, its formation in the gas phase appears highly unlikely. Finally, structures obtained with di-butyltin and di-phenyl tin dichloride are given in the supporting information (Figures S5 and S6). It turns out that in the case of glycine deprotonation, the nature of the organic groups has no influence on the relative energies of the different coordination modes, which, in summary, follows the order $\eta^{2}-\mathrm{O}, \mathrm{NH} 2<\eta^{2}-\mathrm{O}, \mathrm{O}<\eta^{2}-\mathrm{NH}, \mathrm{O}<\eta^{1}-\mathrm{NH}, \mathrm{OH}<<\eta^{1}-$ ZW. Note that replacement of the methyl groups by bulky substituents $(\mathrm{n}-\mathrm{Bu}$ or $\mathrm{Ph}$ ) results in slightly longer Sn-O and Sn-N distances that may suggest a weaker interaction due to steric factors.

In the particular case of the $\left[(\mathrm{n}-\mathrm{Bu})_{2} \mathrm{Sn}(\mathrm{Gly})-\mathrm{H}\right]^{+}$complex, loss of neutral glycine (75 Daltons) is observed upon collision, therefore suggesting that deprotonation may occur onto the butyl group. We then considered deprotonation of the three $\mathrm{CH}_{2}$ groups, intact glycine being either in its neutral or its zwitterionic forms. For a given deprotonation site, the most stable forms are obtained with neutral glycine. Like for dimethyl tin chloride, deprotonation of the methylene group connected to Sn results in structures lying about $170 \mathrm{~kJ} / \mathrm{mol}$ above the DBT- $\eta^{2}-\mathbf{O}, \mathbf{N H 2 - 1}$ form (Figure S5). On the other hand, deprotonation of the next methylene group appears slightly more favourable than deprotonation of glycine $(-5.6 \mathrm{~kJ} / \mathrm{mol})$ at the B3LYP/6-31+G(d,p) level, and gives rise to a structure in which a $[\mathrm{n}-\mathrm{BuSn}(\mathrm{Gly})]^{+}$moiety interacts with a butene molecule. This form (DBT- $\eta^{2}$ - 
O,NH2-3; Figure S5) might account for the loss of neutral glycine specifically observed with this organotin compound. The topological analysis locates a BCP between one of the hydrogen of the amino group and the double bond of butane, with a small electron density $\left(0.014 \mathrm{e} \mathrm{au}^{-3}\right)$. Natural population analysis indicates that the charge transfer towards the metallic center is much more pronounced for this form since a charge of 1.26 is calculated for tin. In this particular structure, tin is triligated and presents a lone pair which is predominantly $5 \mathrm{~s}$, and is polarized by a small $5 \mathrm{p}$ contribution $(\sim 10 \%)$. The natural electron configuration analysis indicates that the electron transfer involves the lone pairs of interacting nitrogen and oxygen, and occurs mostly in the $5 p$ orbitals of tin. As for deprotonation of the third methylene group, it leads to a structure in which $[\mathrm{n}-\mathrm{BuSn}(\mathrm{Gly})]^{+}$and more precisely the metal, interacts with directly with a methyl-cyclopropan (Figure 5S). This structure is about $27 \mathrm{~kJ} / \mathrm{mol}$ less stable than DMT- $\eta^{2}-\mathbf{O}, \mathbf{N H 2 - 1}$ and a significant charge transfer occurs similar reasons. Finally, for diphenyl tin chloride, we considered deprotonation of the ortho position with respect to the Sn-C bond. During the optimization step, a proton from the amino group is transferred onto the carbon initially deprotonated, resulting in the deprotonation of glycine.

Complexes obtained with tri-organotins have also been studied theoretically. As mentioned in the experimental section, tri-organotins interacts with glycine to generate $\left[\left(\mathrm{R}_{3}\right) \operatorname{Sn}(\mathrm{Gly})\right]^{+}$complexes in the gas phase. The isoelectric point $(\mathrm{p} I)$ of glycine being 5.97 , in aqueous solution, glycine should be primarily in its zwitterionic form in $\mathrm{pH} 4-8$ range. While it is well established that the zwitterionic form of glycine is not stable in the gas phase, preformed complexes in solution between metal ions and zwitterionic glycine may be directly transferred in the gas phase by ESI. Furthermore, many theoretical studies have shown ${ }^{57,58,60,61,63-71}$ that zwitterionic glycine can be strongly stabilized through the interaction with metal ions, so that this particular conformation, usually named salt bridge (SB), is generally the global minimum, and can play a key role in the unimolecular reactivity of $\mathrm{M}^{2+} /$ glycine complexes. ${ }^{67}$ 
Figure 4 presents the different forms optimized for the $\left[\left(\mathrm{CH}_{3}\right)_{3} \mathrm{SnGly}\right]^{+}$ions. Structures obtained with TBT- and TPhT are given in the supporting information. Only monodentate interactions have been found. Attempts for bidentate structure with bipyramidal trigonal arrangement systematically collapse towards monodentate tetrahedral species. Both coordination onto the amino and the carboxylic group were considered. Interaction with the carboxylic group always implies the carbonyl oxygen. Structures in which the metal interacts with the hydroxylic oxygen do not correspond to local minima.

NBO calculations show that the charge transfer is even less pronounced for $\left[(\mathrm{R})_{3} \mathrm{Sn}^{+}\right]$as compared to diorganotins, the charge of tin being of 1.95 for this cation, while a value of 1.92 is found when this cation interacts with neutral glycine. The interaction is again mostly ionic, as confirmed by Bader topological analysis. The electron density at the O-Sn BCP is indeed small ( $\sim 0.06$ a.u.), pointing to an ionic linkage.

With neutral glycine, the most favourable coordination site is the carbonyl oxygen. The TMT- $\eta^{1}$-O-2 structure appears indeed particularly stable. However, examination of Figure 4 shows that its stability is in fact imparted to the very strong intramolecular hydrogen bond established between the hydroxyl group and the amino group. Other O-coordinated structures are about $50 \mathrm{~kJ} / \mathrm{mol}$ above the global minimum. In fact, TMT- $\boldsymbol{\eta}^{\mathbf{1}} \mathbf{- O}-\mathbf{2}$ formally corresponds to the interaction of the trimethyltin cation with the second most stable neutral form of glycine ${ }^{55}$ (GlyB, Figure S9). Comparison of the geometry of this neutral form with that of glycine in this complex, shows that the interaction only results in a C-O bond elongation comparable to that observed for di-organotins $(0.3 \AA)$. The longer $\mathrm{Sn}-\mathrm{O}$ distance $(\sim 2.250 \AA)$ suggests that the interaction is weaker than for di-organotins. This is consistent with our experimental results since the only fragmentation upon CID is the loss of intact glycine. Comparison between TMT- $\eta^{1}-\mathbf{O}-3$ and neutral glycine GlyC (Figure S9) shows that like di-organotins a 
weakening of the two long-range $\mathrm{NH} . . \mathrm{O}=\mathrm{C}$ interactions is observed. This should therefore results in the decrease of the rotational barrier associated to the interconversion of TMT- $\eta^{1}-0-3$ towards TMT- $\eta^{1}-0-2$.

Interaction of trimethyltin with the amino group results in structure located about 20-40 $\mathrm{kJ} / \mathrm{mol}$ above the global minimum. Again, an important stabilization occurs when an intramolecular hydrogen bond can be established.

Although the neutral glycine ligand has not been observed in the zwitterionic form in the gas phase, the zwitterion is greatly stabilized through the interaction with tri-organotins. It is actually the global minimum for trimethyltin, while with bulkier substituents, the energy difference is only few $\mathrm{kJ} / \mathrm{mol}$. According to Figure 4, we can see that TMT- $\boldsymbol{\eta}^{\mathbf{1}}-\mathbf{O}-\mathbf{2}$ and TMT- $\boldsymbol{\eta}^{\mathbf{1}}-\mathbf{Z W}-\mathbf{1}$ are practically degenerated. These two structures may interconvert through migration of a proton between the hydroxyl and the amino group. We estimated the activation barrier associated with this proton shift and obtained a value of $3 \mathrm{~kJ} / \mathrm{mol}$ at the B3LYP/6-31+G(d,p) level. This activation barrier is therefore very low, as also observed for other metal ions ${ }^{57}$. Consequently, these two structures may coexist in the gas phase.

\section{Mechanisms of fragmentations}

Use of labeled glycines provides useful insights about the dissociation mechanisms involved in the fragmentation processes, and this section aims at proposing several mechanisms accounting for the main fragment ions. Elimination of 18, 28 and $46 \mathrm{u}$ are typical of metal/glycine complexes unimolecular reactivity. As already discussed previously and summarized in Table 1, the loss of 28 Daltons systematically involves the carbonyl group of the glycine and is attributed to the elimination of $\mathrm{CO}$. In addition, use of 2,2- $\mathrm{D}_{2}$-glycine shows that the hydrogen atoms eliminated in water are labile hydrogens. This reactivity 
therefore differs from that of $[\mathrm{Pb}(\mathrm{Gly})-\mathrm{H}]^{+}$complex ${ }^{44}$. Finally, the $46 \mathrm{u}$ moiety elimination both includes the carbonyl group and two labile hydrogens. One may reasonably assume that it corresponds to successive elimination of $\mathrm{H}_{2} \mathrm{O}+\mathrm{CO}$ since both losses of $\mathrm{CO}$ and $\mathrm{H}_{2} \mathrm{O}$ are observed. Furthermore, previous experimental and theoretical studies both on protonated glycine ${ }^{48}$ and $\mathrm{Cu}^{+} /$glycine ${ }^{43}$ demonstrated that elimination of $\mathrm{H}_{2} \mathrm{O}+\mathrm{CO}$ is energetically and/or kinetically preferred over loss $\mathrm{H}_{2}+\mathrm{CO}_{2}$ or formic acid. Consequently, based upon previous and present results we propose the mechanism displayed in Scheme 2 in order to explain the formation of ions arising from the loss of 18, 28 and $46 \mathrm{u}$.

$<$ Scheme 2>

Previous theoretical studies about the interaction of $\mathrm{Ni}^{+42}$ and $\mathrm{Cu}^{+43}$ with glycine have shown that the most favourable dissociation pathways implies as a first step insertion of the metal into the C-C bond. Starting from a $\eta^{2}$-NH,O-like structure, which can be particularly stable (Figure 3) and eventually formed from the global minimum by a suitable $\mathrm{H}$ shift, insertion into the $\mathrm{C}-\mathrm{C}$ bond leads to an intermediate in which $\mathrm{Sn}$ interacts with a $\mathrm{COOH}$ moiety and formaldimine. Elimination of the latter would be consistent with the loss of $29 \mathrm{u}$ experimentally observed. Alternatively, further metal insertion into the $\mathrm{C}-\mathrm{O}$ would generate a transient species in which the $(\mathrm{R})_{2} \mathrm{Sn}$ moiety interacts with $\mathrm{CO}$, formaldimine, and $\mathrm{OH}$. Successive loss of $\mathrm{CH}_{2}=\mathrm{NH}$ and $\mathrm{CO}$ would generate the $\left[\left(\mathrm{R}_{2}\right) \mathrm{SnOH}\right]^{+}$cation $(-57 \mathrm{u})$ present on the MS/MS spectra. Subsequent proton transfer from formaldimine to the hydroxyl group would lead to a water ligand with two labile protons, as observed experimentally. Then, sequential elimination of water and carbon monoxide would account for the elimination of 18 , 28 and $46 \mathrm{u}$. Note that formation of $\left[(\mathrm{R})_{2} \mathrm{SnOH}\right]^{+}$might also arise from a $\boldsymbol{\eta}^{\mathbf{2}}-\mathbf{N H}, \mathbf{O H}-$ like complex (Scheme 2) that would undergo a C-O metal insertion resulting in the transfer of the $\mathrm{OH}$ group onto the metallic center, followed by ring closure and elimination of aziridinone. 
Another important fragmentation corresponds to the formation of $\left[(\mathrm{R})_{2} \mathrm{SnH}\right]^{+}$ion. Our experiments have demonstrated that the hydrogen atom comes exclusively from the methylene group. Mechanisms accounting for its formation are proposed in Scheme 3 and involve the INT1 and INT2 intermediates (arising from $\boldsymbol{\eta}^{\mathbf{2}}-\mathbf{O}, \mathbf{N H}_{\mathbf{2}}$ and $\boldsymbol{\eta}^{\mathbf{2}} \mathbf{- N H}, \mathbf{O}$ structures, respectively), through $\mathrm{C}-\mathrm{H}$ insertion and subsequent elimination of an acyclic fragment, that may be viewed as a formaldimine substituted by a carboxylic group.

\section{$\langle$ Scheme 3>}

Finally, a mechanism is also proposed for the formation of the $\left[(\mathrm{R})_{2} \mathrm{SnNH}_{2}\right]^{+}$species. This ion is characterized by the presence of two exchangeable protons. Starting from a $\boldsymbol{\eta}^{2}-\mathbf{O}, \mathbf{N H}_{2}$ complex, a reasonable mechanism would imply transfer of the amino group onto Sn by C-N bond insertion. Then, formation of $\left[(\mathrm{R})_{2} \mathrm{SnNH}_{2}\right]^{+}$would be accompanied by elimination of $\alpha-$ acetolactone.

\section{Conclusion}

In conclusion, this study shows that di-and tri-organotins exhibit a different behavior in presence of the amino acid. Under ESI conditions, the tri-organotins lead to a single type of complex, namely $\left[(\mathrm{R})_{3} \mathrm{SnGly}\right]^{+}$, whose MS/MS spectra only showed elimination of intact glycine, leading to the formation of the $\left[(\mathrm{R})_{3} \mathrm{Sn}\right]^{+}$carbocation. Calculations showed that the interaction is purely electrostatic. $\left[(\mathrm{R})_{3} \mathrm{Sn}\right]^{+}$strongly stabilizes the zwitterionic form of glycine, which is practically degenerate with respect to neutral glycine. In addition, the interconversion between both forms is almost barrierless.

On the other hand, di-organotins formally promote deprotonation of glycine, leading to $\left[(\mathrm{R})_{2} \mathrm{Sn}(\mathrm{Gly})-\mathrm{H}\right]^{+}$complexes. The unimolecular reactivity upon collision of these complexes is radically different, characterized by numerous fragmentation processes. For these systems, 
calculations pointed to a preferable bidentate interaction of the type $\eta^{2}-\mathbf{O}, \mathbf{N H 2}$, similar to that encountered for other metal ions. Use of labelled glycine gave useful insights in order to propose mechanism accounting for the most relevant fragmentation processes.

\section{Ackowledgments}

Authors would like the computational center of the "Universidad Autonoma de Madrid" for computational time.

\section{Supporting Information}

Additional electrospray and MS/MS spectra of the various complexes are provided as supplementary material. Supporting information also includes structures and energies of all the computed geometries for the different systems. 
1. Guard HE, Cobet AB, Coleman WM. Methylation Of Trimethyltin Compounds By Estuarine Sediments. Science 1981; 213: 770-771.

2. Yngve V in Stabilized vinyl eesins, Vol. 2219463 (Ed.^Eds.: United States of America, 1940, p.^pp.

3. van der Kerk GJM. Present status of the use of organotin compounds. Chem. Ztg 1975; 99: 26-32.

4. Hoch M. Organotin compounds in the environment - an overview. Appl. Geochem. 2001; 16: 719-743.

5. Rose MS. Evidence For Histidine In Triethyltin-Binding Site Of Rat Haemoglobin. Biochem. J 1969; 111: 129-137.

6. Rose MS, Lock EA. Interaction Of Triethyltin With A Component Of Guinea-Pig Liver Supernatant - Evidence For Histidine In Binding Sites. Biochem. J 1970; 120: 151-157.

7. Farrow BG, Dawson AP. Investigation Of Interaction Of Triethyltin With Rat-Liver Mitochondria Using Binding Studies And Mossbauer-Spectroscopy. Eur. J. Biochem. 1978; 86: 85-95.

8. Crowe AJ, Smith PJ, Cardin CJ, Parge HE, Smith FE. Possible Pre-Dissociation Of Diorganotin Dihalide Complexes - Relationship Between Antitumour Activity And Structure. Cancer Letters 1984; 24: 45-48.

9. Gielen $\mathrm{M}$, Lelieveld $\mathrm{P}$, Devos D, Pan H, Willem R, Biesemans $\mathrm{M}$, Fiebig HH. Invitro Effect Of Organotin-Substituted Steroids In Human Tumor-Cell Lines. Inorg. Chim. Acta 1992; 196: 115117.

10. Gielen M, Elkhloufi A, Biesemans M, Willem R, Meunierpiret J. (2-Methylthio-3Pyridinecarboxylato)-Diethyltin And -Di-N-Butyltin Compounds - Synthesis, Spectroscopic Characterization And Invitro Antitumor-Activity - X-Ray Crystal-Structure Of Bis[Diethyl(2Methylthio-3-Pyridinecarboxylato)Tin] Oxide And Of Diethyltin Bis(2-Methylthio-3Pyridinecarboxylate). Polyhedron 1992; 11: 1861-1868.

11. Casas JS, Castineiras A, Couce MD, Playa N, Russo U, Sanchez A, Sordo J, Varela JM. Supramolecular organization in catena-poly\{diethyl[3-(2-pyridyl)-2sulfanylpropenoato]tin(IV)\} and related diorganotin(IV) sulfanylcarboxylato compounds. J. Chem. Soc., Dalton Trans. 1998; 1513-1521.

12. Xueqing $S$, Zhiqiang $Y$, Qinglan $X$, Jinshan L. Synthesis, structures and in vitro antitumor activity of some germanium-substituted di-n-butyltin dipropionates. J. Organomet. Chem. 1998; 566: 103-110.

13. Kemmer M, Dalil H, Biesemans M, Martins JC, Mahieu B, Horn E, de Vos D, Tiekink ERT, Willem R, Gielen M. Dibutyltin perfluoroalkanecarboxylates: synthesis, NMR characterization and in vitro antitumour activity. J. Organomet. Chem. 2000; 608: 63-70.

14. Camacho CC, de Vos D, Mahieu B, Gielen M, Kemmer M, Biesemans M, Willem R. Organotin(IV) derivatives of 3,4-(methylenedioxy)phenylacetic acid: Synthesis, spectroscopic characterization and in vitro antitumour properties. Main Group Met. Chem. 2000; 23: 433438. 
15. Gielen $M$, Biesemans $M$, de Vos D, Willem R. Synthesis, characterization and in vitro antitumor activity of di- and triorganotin derivatives of polyoxa- and biologically relevant carboxylic acids. J. Inorg. Biochem. 2000; 79: 139-145.

16. Barbieri R. Qsar Approach To Understand The Antitumor-Activity Of Organotins. Inorg. Chim. Acta 1992; 191: 253-259.

17. Gupta SP. Quantitative Structure-Activity Relationship Studies On Anticancer Drugs. Chem. Rev. 1994; 94: 1507-1551.

18. In Nato ASI Series, Tin-Based Antitumour Drugs, (eds). Springer-Verlag New-York, 1990;

19. Gielen M. Review: Organotin compounds and their therapeutic potential: a report from the Organometallic Chemistry Department of the Free University of Brussels. Appl. Organomet. Chem. 2002; 16: 481-494.

20. Tabassum S, Pettinari C. Chemical and biotechnological developments in organotin cancer chemotherapy. J. Organomet. Chem. 2006; 691: 1761-1766.

21. Gharib F, Jaberi F, Zandevakili M. Interaction of dimethyltin(IV) dichloride with 5'-IMP and 5'UMP. Appl. Organomet. Chem. 2008; 22: 215-220.

22. Surdy P, Rubini P, Buzas N, Henry B, Pellerito L, Gajda T. Interaction of dimethyltin(IV)(2+) cation with Gly-Gly, Gly-His, and some related ligands. A new case of a metal ion able to promote peptide nitrogen deprotonation in aqueous solution. Inorg. Chem. 1999; 38: 346352.

23. Nath M, Pokharia S, Yadav R. Organotin(IV) complexes of amino acids and peptides. Coord. Chem. Rev. 2001; 215: 99-149.

24. Pellerito L, Nagy L. Organotin(IV)( $n+)$ complexes formed with biologically active ligands: equilibrium and structural studies, and some biological aspects. Coord. Chem. Rev. 2002; 224: 111-150.

25. Gharib F, Farzad E, Amini MM. Interaction of dimethyltin(IV)dichloride with 5 '-AMP and 5 'GMP. Canadian Journal Of Chemistry-Revue Canadienne De Chimie 2006; 84: 1534-1540.

26. Domazetis G, Magee RJ, James BD. Organotin (IV) derivatives of L-cysteine and DLpenicillamine. J. Organomet. Chem. 1978; 162: 239-252.

27. Hynes MJ, Odowd M. Interactions Of The Trimethyltin(Iv) Cation With Carboxylic-Acids, Amino-Acids, And Related Ligands. J. Chem. Soc., Dalton Trans. 1987; 563-566.

28. Silvestri A, Duca D, Huber F. A study of dimethyltin(IV)-L-cysteinate in aqueous solution. Appl. Organomet. Chem. 1988; 2: 417-425.

29. Buzás N, Gajda T, Kuzmann E, Nagy L, Vertes A, Burger K. COORDINATION PROPERTIES OF LCYSTEINE AND ITS DERIVATIVES TOWARDS DIETETHYLTIN(IV) IN AQUEOUS SOLUTION. Main Group Met. Chem. 1995; 18: 641-649.

30. Chernushevich IV, Loboda AV, Thomson BA. An introduction to quadrupole-time-of-flight mass spectrometry. J. Mass Spectrom. 2001; 36: 849-865.

31. Frisch MJ, Trucks GW, Schlegel HB, Scuseria GE, Robb MA, Cheeseman JR, Zakrzewski VG, Montgomery JAJ, Stratmann RE, Burant JC, Dapprich S, Millam JM, Daniels AD, Kudin KN, Strain MC, Farkas O, Tomasi J, Barone V, Cossi M, Cammi R, Mennucci B, Pomelli C, Adamo C, Clifford S, Ochterski J, Petersson GA, Ayala PY, Cui Q, Morokuma K, Malick DK, Rabuck AD, Raghavachari K, Foresman JB, Cioslowski J, Ortiz JV, Stefanov BB, Liu G, Liashenko A, Piskorz P, Komaromi I, Gomperts R, Martin RL, Fox DJ, Keith T, Al-Laham MA, Peng CY, Nanayakkara 
A, Gonzalez C, Challacombe M, Gill PMW, Johnson B, Chen W, Wong MW, Andres JL, HeadGordon M, Replogle ES, Pople JA. Gaussian03, Revised E1. Gaussian, Inc. Pittsburgh PA. 2004.

32. Lee C, Yang W, Parr RG. Development of the Colle-Salvetti correlation-energy formula into a functional of the electron density. Phys. Rev. B 1988; 37: 785-789.

33. Becke AD. Density functional thermochemistry. III. The role of exact exchange. J. Chem. Phys. 1993; 98: 5648-5652.

34. Metz B, Stoll H, Dolg M. Small-core multiconfiguration-Dirac-Hartree-Fock-adjusted pseudopotentials for post-d main group elements: Application to $\mathrm{PbH}$ and $\mathrm{PbO}$. J. Chem. Phys. 2000; 113: 2563-2569.

35. Scott AP, Radom L. Harmonic vibrational frequencies: An evaluation of Hartree-Fock, MollerPlesset, quadratic configuration interaction, density functional theory, and semiempirical scale factors. J. Phys. Chem 1996; 100: 16502-16513.

36. Bader RFW. In Atoms in Molecules. A Quantum Theory, (eds). Clarendon Press: Oxford, 1990;

37. Bader RFW, Cheeseman JR. AIMPAC 2000,2000.

38. Moision RM, Armentrout PB. Experimental and theoretical dissection of sodium cation/glycine interactions. J. Phys. Chem. A 2002; 106: 10350-10362.

39. Moision RM, Armentrout PB. An experimental and theoretical dissection of potassium cation/glycine interactions. Phys. Chem. Chem. Phys. 2004; 6: 2588-2599.

40. Bowman VN, Heaton AL, Armentrout PB. Metal Cation Dependence of Interactions with Amino Acids: Bond Energies of Rb+ to Gly, Ser, Thr, and Pro. J. Phys. Chem. B 2010; 114: 4107-4114.

41. Armentrout PB, Chen $\mathrm{Y}$, Rodgers MT. Metal Cation Dependence of Interactions with Amino Acids: Bond Energies of Cs+ to Gly, Pro, Ser, Thr, and Cys. J. Phys. Chem. A 2012; 116: 39893999.

42. Rodriguez-Santiago L, Sodupe M, Tortajada J. Gas-phase reactivity of Ni+ with glycine. J. Phys. Chem. A 2001; 105: 5340-5347.

43. Hoppilliard Y, Ohanessian G, Bourcier S. Fragmentation Mechanisms of Glycine-Cu+ in the Gas Phase. An Experimental and Theoretical Study. J. Phys. Chem. A 2004; 108: 9687-9696.

44. Atkins CG, Banu L, Rowsell M, Blagojevic V, Bohme DK, Fridgen TD. Structure of $[\mathrm{Pb}(\mathrm{Gly}-\mathrm{H})](+)$ and the Monosolvated Water and Methanol Solvated Species by Infrared Multiple-Photon Dissociation Spectroscopy, Energy-Resolved Collision-Induced Dissociation, and Electronic Structure Calculations. J. Phys. Chem. B 2009; 113: 14457-14464.

45. Rogalewicz F, Hoppilliard Y, Ohanessian G. Structures and fragmentations of zinc(II) complexes of amino acids in the gas phase. I. Electrosprayed ions which are structurally different from their liquid phase precursors. Int. J. Mass Spectrom. 2000; 201: 307-320.

46. Hoppilliard Y, Rogalewicz F, Ohanessian G. Structures and fragmentations of zinc(II) complexes of amino acids in the gas phase. II. Decompositions of glycine-Zn(II) complexes. Int. J. Mass Spectrom. 2001; 204: 267-280.

47. Rogalewicz F, Hoppilliard Y, Ohanessian G. Structures and fragmentations of zinc(II) complexes of amino acids in the gas phase. III. Rearrangement versus desolvation in the electrospray formation of the glycine-zinc complex. Int. J. Mass Spectrom. 2001; 206: 45-52. 
48. Rogalewicz F, Hoppilliard Y, Ohanessian G. Fragmentation mechanisms of alpha-amino acids protonated under electrospray ionization: a collisional activation and ab initio theoretical study. Int. J. Mass Spectrom. 2000; 196: 565-590.

49. Blomberg $\mathrm{M}$, Yi SS, Noll RJ, Weisshaar JC. Gas-phase $\mathrm{Ni}^{+}\left({ }^{2} \mathrm{D}_{5 / 2}\right)+n-\mathrm{C}_{4} \mathrm{H}_{10}$ reaction dynamics in real time: Experiment and statistical modeling based on density functional theory. J. Phys. Chem. A 1999; 103: 7254-7267.

50. Reichert EL, Yi SS, Weisshaar JC. Bimolecular ion-molecule collisions in real time: Co+(F-3(4)) plus n-butane and isobutane reactions. Int. J. Mass Spectrom. 2000; 55-69.

51. Mó O, Yáñez M, Salpin JY, Tortajada J. Thermochemistry, bonding, and reactivity of $\mathrm{Ni}^{+}$and $\mathrm{Ni}^{2+}$ in the gas phase. Mass Spectrom. Rev. 2007; 26: 474-516.

52. Roithova J, Schroder D. Selective Activation of Alkanes by Gas-Phase Metal lons. Chem. Rev. 2010; 110: 1170-1211.

53. Arena G, CalÃ $\neg$ R, Contino A, Musumeci A, Musumeci S, Purrello R. Coordination properties of dialkyltin (IV) in aqueous solution. Thermodynamic study of dimethyltin (IV) complexes with I-amino acids. Inorg. Chim. Acta 1995; 237: 187-191.

54. O'Hair RAJ, Blanksby S, Styles M, Bowie JH. Characterization of [M-H] cations, radicals and anions of glycine in the gas phase: a combined experimental and ab initio study. Int. J. Mass Spectrom. 1999; 182-183: 203-211.

55. Hoyau S, Ohanessian G. Absolute affinities of alpha-amino acids for $\mathrm{Cu}+$ in the gas phase. A theoretical study. J. Am. Chem. Soc. 1997; 119: 2016-2024.

56. Glendening ED, Reed AE, Weinhold F. NBO version 3.1.,

57. Pulkkinen S, Noguera M, Rodriguez-Santiago L, Sodupe M, Bertran J. Gas phase intramolecular proton transfer in cationized glycine and chlorine substituted derivatives (Mgly, $\mathrm{M}=\mathrm{Na}+, \mathrm{Mg} 2+, \mathrm{Cu}+, \mathrm{Ni}+$, and $\mathrm{Cu} 2+)$ : Existence of zwitterionic structures? Chem. Eur. J. 2000; 6: 4393-4399.

58. Hoyau S, Pelicier JP, Rogalewicz F, Hoppilliard Y, Ohanessian G. Complexation of glycine by atomic metal cations in the gas phase. Eur. J. Mass Spectrom. 2001; 7: 303-311.

59. Kapota C, Lemaire J, Maitre P, Ohanessian G. Vibrational signature of charge solvation vs salt bridge isomers of sodiated amino acids in the gas phase. J. Am. Chem. Soc. 2004; 126: 18361842.

60. Remko M, Rode BM. Effect of Metal lons ( $\mathrm{Li}+, \mathrm{Na}+, \mathrm{K}+, \mathrm{Mg} 2+, \mathrm{Ca} 2+, \mathrm{Ni2}+, \mathrm{Cu} 2+$, and $\mathrm{Zn} 2+$ ) and Water Coordination on the Structure of Glycine and Zwitterionic Glycine. J. Phys. Chem. A 2006; 110: 1960-1967.

61. Bertran J, Rodriguez-Santiago L, Sodupe M. The different nature of bonding in Cu+-glycine and Cu2+-glycine. J. Phys. Chem. B 1999; 103: 2310-2317.

62. Shoeib T, Rodriquez CF, Siu KWM, Hopkinson AC. A comparison of copper(I) and silver(I) complexes of glycine, diglycine and triglycine. Phys. Chem. Chem. Phys. 2001; 3: 853-861.

63. Constantino E, Rodriguez-Santiago L, Sodupe M, Tortajada J. Interaction of $\mathrm{Co}+$ and $\mathrm{Co}+$ with glycine. A theoretical study. J. Phys. Chem. A 2005; 109: 224-230.

64. Rogalewicz F, Ohanessian G, Gresh N. Interaction of neutral and zwitterionic glycine with $\mathrm{Zn} 2+$ in gas phase: $\mathrm{Ab}$ initio and SIBFA molecular mechanics calculations. J. Comput. Chem. 2000; 21: 963-973. 
65. Strittmatter EF, Lemoff AS, Williams ER. Structure of cationized glycine, gly center dot M2+ $(\mathrm{M}=\mathrm{Be}, \mathrm{Mg}, \mathrm{Ca}, \mathrm{Sr}, \mathrm{Ba})$, in the gas phase: Intrinsic effect of cation size on zwitterion stability. J. Phys. Chem. A 2000; 104: 9793-9796.

66. Ai H, Bu Y, Li P. Intramolecular proton transfer induced by divalent alkali earth metal cation in the gas state. Int. J. Quantum Chem. 2003; 94: 205-214.

67. Corral I, Mo O, Yanez M, Salpin JY, Tortajada J, Moran D, Radom L. An experimental and theoretical investigation of gas-phase reactions of Ca2+ with glycine. Chem. Eur. J. 2006; 12: 6787-6796.

68. Marino T, Toscano M, Russo N, Grand A. Structural and electronic characterization of the complexes obtained by the interaction between bare and hydrated first-row transition-metal ions (Mn2+, $\mathrm{Fe} 2+, \mathrm{Co} 2+, \mathrm{Ni2}+, \mathrm{Cu} 2+, \mathrm{Zn2+})$ and glycine. J. Phys. Chem. B 2006; 110: 2466624673 .

69. Bush MF, Oomens J, Saykally RJ, Williams ER. Effects of alkaline earth metal ion complexation on amino acid zwitterion stability: Results from infrared action spectroscopy. J. Am. Chem. Soc. 2008; 130: 6463-6471.

70. Khodabandeh $\mathrm{MH}$, Davari MD, Zahedi M, Ohanessian G. Complexation of glycine by manganese (II) in the gas phase: A theoretical study. Int. J. Mass Spectrom. 2010; 291: 73-83.

71. Corral I, Lamsabhi A, Mo O, Yanez M. Infrared spectra of charge-solvated versus salt-bridge conformations of glycine-, serine-, and cysteine-Ca2+ complexes. Int. J. Quantum Chem. 2012; 112: 2126-2134. 


\section{Figure captions}

Figure 1. Positive nano-electrospray spectra of a mixture glycine/OTC ([Gly] $=5 \times 10^{-4} \mathrm{M}$, $\left.[\mathrm{OTC}]=10^{-4} \mathrm{M}\right)$ in methanol/water $(50 / 50 \mathrm{v} / \mathrm{v})$ recorded with a DP of 50V. a) OTC $=$ DMTCl and b) OTC $=$ TMTCl.

Figure 2. CID spectra of $\left[\left(\mathrm{CH}_{3}\right)_{2} \mathrm{SnGly}-\mathrm{H}\right]^{+}$complex obtained with a) unlabeled glycine b) 1${ }^{13} \mathrm{C}$-glycine and c) 2,2- $\mathrm{d}_{2}$-glycine recorded with a collision energy of $15 \mathrm{eV}$ (laboratory frame).

Figure 3. Summary of the global minima found for the $\left[\left(\mathrm{CH}_{3}\right)_{2} \mathrm{Sn}(\mathrm{Gly})-\mathrm{H}\right]^{+}$complex. Relative enthalpies are given in $\mathrm{kJ} / \mathrm{mol}$ and bond lengths in Angströms. See text for details ion.

Figure 4. Summary of the global minima found for the $\left[\left(\mathrm{CH}_{3}\right)_{3} \mathrm{Sn}(\mathrm{Gly})\right]^{+}$complex. Relative enthlapies are given in kJ/mol and bond lengths in Angströms. See text for details ion.

Scheme 1. global fragmentation pathways of the $\left[(\mathrm{R})_{2} \mathrm{SnGly}-\mathrm{H}\right]^{+}$.

Scheme 2. Fragmentation pathways of $\left[(\mathrm{R})_{2} \mathrm{SnGly}-\mathrm{H}\right]^{+}$.

Scheme 3. Proposed mechanism for the formation of $\left[(\mathrm{R})_{2} \mathrm{SnH}\right]^{+}$. 
Table 1: product ions observed in the fragmentation of different labeled glycine-OTs species.

\begin{tabular}{|c|c|c|c|c|c|c|c|c|}
\hline Glycine & Precursor ion & Product ions & & & & & & \\
\hline & {$\left[\left(\mathrm{CH}_{3}\right)_{2} \mathrm{SnGly}-\mathrm{H}\right]^{+}$} & $-\mathrm{H}_{2} \mathrm{O}$ & $-\mathrm{CO}$ & $-\mathrm{CO}, \mathrm{H}_{2} \mathrm{O}$ & $\left(\mathrm{CH}_{3}\right)_{2} \mathrm{SnOH}^{+}$ & $\left(\mathrm{CH}_{3}\right)_{2} \mathrm{SnH}^{+}$ & $\left(\mathrm{CH}_{3}\right) \mathrm{Sn}^{+}$ & $\left(\mathrm{CH}_{3}\right)_{2} \mathrm{SnNH}_{2}^{+}$ \\
\hline not labelled & $\mathrm{m} / \mathrm{z} 223.98$ & $m / z 205.96$ & $m / z 195.98$ & $\mathrm{~m} / \mathrm{z} 177.97$ & $\mathrm{~m} / \mathrm{z} 166.96$ & $\mathrm{~m} / \mathrm{z} 150.96$ & $\mathrm{~m} / \mathrm{z} 134.94$ & $\mathrm{~m} / \mathrm{z} 165.98$ \\
\hline $1-{ }^{13} \mathrm{C}$ & $\mathrm{m} / \mathrm{z} 224.97$ & $\mathrm{~m} / \mathrm{z} 206.96$ & $\mathrm{~m} / z 195.97$ & $\mathrm{~m} / \mathrm{z} 177.97$ & $\mathrm{~m} / \mathrm{z} 166.95$ & $\mathrm{~m} / \mathrm{z} 150.96$ & $\mathrm{~m} / \mathrm{z} 134.94$ & $\mathrm{~m} / \mathrm{z} 165.98$ \\
\hline \multirow[t]{2}{*}{$2,2-\mathrm{d}_{2}$} & $\mathrm{~m} / \mathrm{z} 225.98$ & $\mathrm{~m} / \mathrm{z} 207.97$ & $m / z 197.99$ & $\mathrm{~m} / \mathrm{z} 179.98$ & $\mathrm{~m} / \mathrm{z} 166.95$ & $\mathrm{~m} / \mathrm{z} 151.96$ & $\mathrm{~m} / \mathrm{z} 134.94$ & $\mathrm{~m} / \mathrm{z} 165.98$ \\
\hline & {$\left[(\mathrm{n}-\mathrm{Bu})_{2} \mathrm{SnGly}-\mathrm{H}\right]^{+}$} & $-\mathrm{H}_{2} \mathrm{O}$ & $-\mathrm{CO}$ & $-\mathrm{CO}, \mathrm{H}_{2} \mathrm{O}$ & $(\mathrm{n}-\mathrm{Bu})_{2} \mathrm{SnOH}^{+}$ & {$\left[(\mathrm{n}-\mathrm{Bu})_{2} \mathrm{SnH}\right]^{+}$} & $\mathrm{n}-\mathrm{BuSn}^{+}$ & $(\mathrm{n}-\mathrm{Bu})_{2} \mathrm{SnNH}_{2}{ }^{+}$ \\
\hline not labelled & $\mathrm{m} / \mathrm{z} 308.06$ & $\mathrm{~m} / \mathrm{z} 290.05$ & $\mathrm{~m} / \mathrm{z} 280.06$ & $\mathrm{~m} / \mathrm{z} 262.00$ & $\mathrm{~m} / \mathrm{z} 251.04$ & $\mathrm{~m} / \mathrm{z} 235.04$ & $\mathrm{~m} / \mathrm{z} 176.97$ & $\mathrm{~m} / \mathrm{z} 250.03$ \\
\hline $1-{ }^{13} \mathrm{C}$ & $\mathrm{m} / \mathrm{z} 309.04$ & $\mathrm{~m} / \mathrm{z} 291.04$ & $\mathrm{~m} / \mathrm{z} 280.06$ & $\mathrm{~m} / \mathrm{z} 262.00$ & $\mathrm{~m} / \mathrm{z} 251.02$ & $\mathrm{~m} / \mathrm{z}^{2} 235.03$ & $\mathrm{~m} / \mathrm{z} 176.96$ & $\mathrm{~m} / \mathrm{z} 250.03$ \\
\hline \multirow[t]{2}{*}{$2,2-\mathrm{d}_{2}$} & $\mathrm{~m} / \mathrm{z} 310.06$ & $\mathrm{~m} / \mathrm{z} 292.05$ & $\mathrm{~m} / \mathrm{z} 282.06$ & $\mathrm{~m} / \mathrm{z} 264.00$ & $\mathrm{~m} / \mathrm{z} 251.02$ & $\mathrm{~m} / \mathrm{z} 236.04$ & $\mathrm{~m} / \mathrm{z} 176.96$ & $\mathrm{~m} / \mathrm{z} 250.03$ \\
\hline & {$\left[(\mathrm{Ph})_{2} \mathrm{SnGly}-\mathrm{H}\right]^{+}$} & $-\mathrm{H}_{2} \mathrm{O}$ & $-\mathrm{CO}$ & $-\mathrm{CO}, \mathrm{H}_{2} \mathrm{O}$ & $(\mathrm{Ph})_{2} \mathrm{SnOH}^{+}$ & $(\mathrm{Ph})_{2} \mathrm{SnH}^{+}$ & $\mathrm{PhSn}^{+}$ & $(\mathrm{Ph})_{2} \mathrm{SnNH}_{2}^{+}$ \\
\hline not labelled & $\mathrm{m} / \mathrm{z} 347.99$ & $m / z 329.98$ & $m / z 320.00$ & $m / z 301.98$ & $\mathrm{~m} / \mathrm{z} 290.96$ & $\mathrm{~m} / \mathrm{z} 274.97$ & $m / z 196.94$ & $\mathrm{~m} / \mathrm{z} 290.00$ \\
\hline $1-{ }^{13} \mathrm{C}$ & $\mathrm{m} / \mathrm{z} 348.98$ & $\mathrm{~m} / \mathrm{z} 330.97$ & $\mathrm{~m} / \mathrm{z} 320.00$ & $m / z 301.98$ & $\mathrm{~m} / \mathrm{z} 290.95$ & $\mathrm{~m} / \mathrm{z} 274.97$ & $\mathrm{~m} / \mathrm{z} 196.93$ & $\mathrm{~m} / \mathrm{z} 290.00$ \\
\hline \multirow[t]{2}{*}{$2,2-\mathrm{d}_{2}$} & $\mathrm{~m} / \mathrm{z} 349.98$ & $\mathrm{~m} / \mathrm{z} 331.98$ & $\mathrm{~m} / \mathrm{z} 322.00$ & $\mathrm{~m} / \mathrm{z} 302.98$ & $\mathrm{~m} / \mathrm{z} 290.95$ & $\mathrm{~m} / \mathrm{z} 275.97$ & $\mathrm{~m} / \mathrm{z} 196.93$ & $\mathrm{~m} / \mathrm{z} 290.00$ \\
\hline & {$\left[\left(\mathrm{CH}_{3}\right)_{3} \mathrm{SnGly}\right]^{+}$} & $\left(\mathrm{CH}_{3}\right)_{3} \mathrm{Sn}^{+}$ & & & & & & \\
\hline not labelled & $\mathrm{m} / \mathrm{z} 240.00$ & $\mathrm{~m} / \mathrm{z} 164.97$ & & & & & & \\
\hline $1-{ }^{13} \mathrm{C}$ & $\mathrm{m} / \mathrm{z} 241.00$ & $\mathrm{~m} / \mathrm{z} 164.97$ & & & & & & \\
\hline $2,2-\mathrm{d}_{2}$ & $\mathrm{~m} / \mathrm{z} 242.01$ & $\mathrm{~m} / \mathrm{z} 164.97$ & & & & & & \\
\hline
\end{tabular}



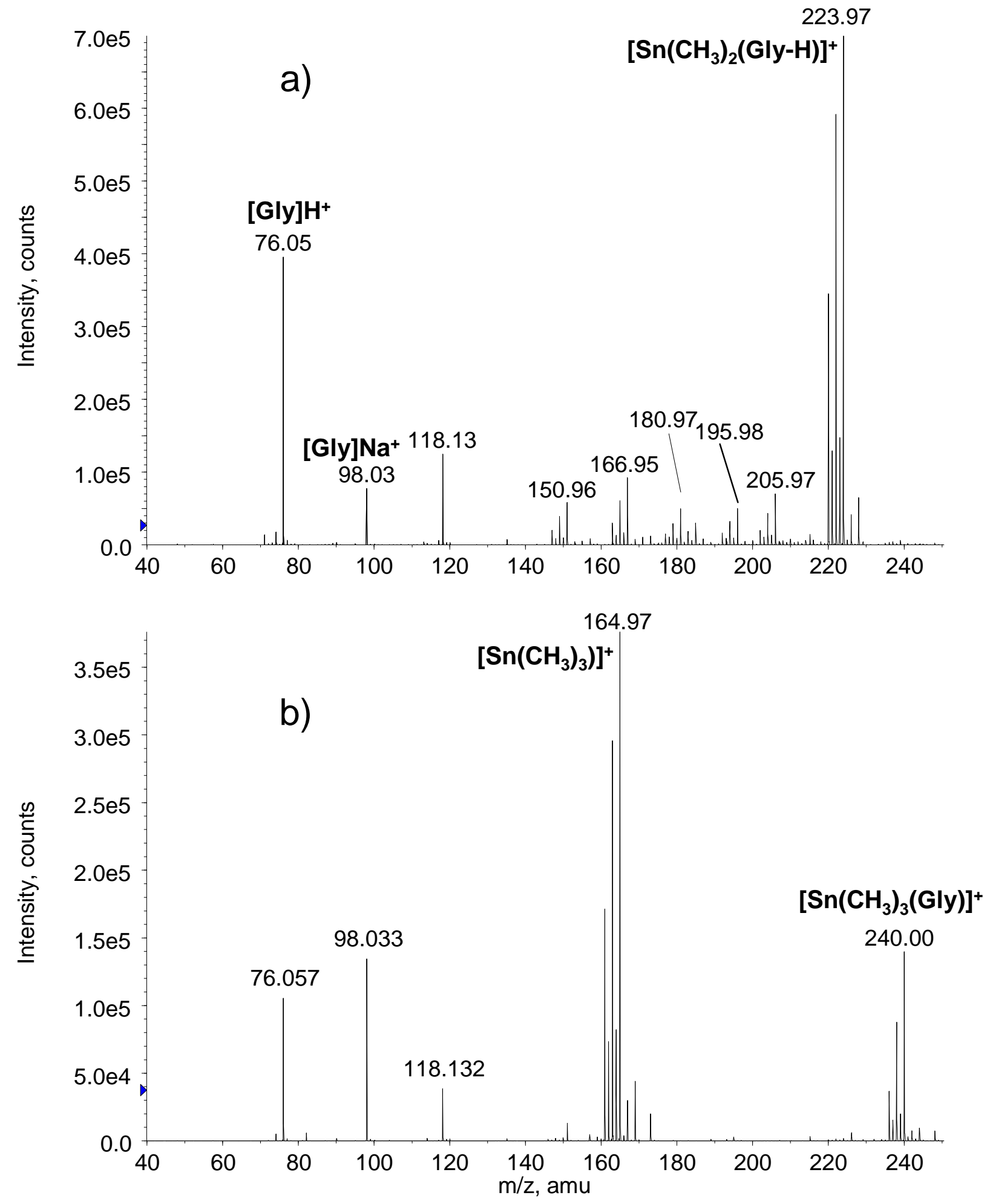

Figure 1. 

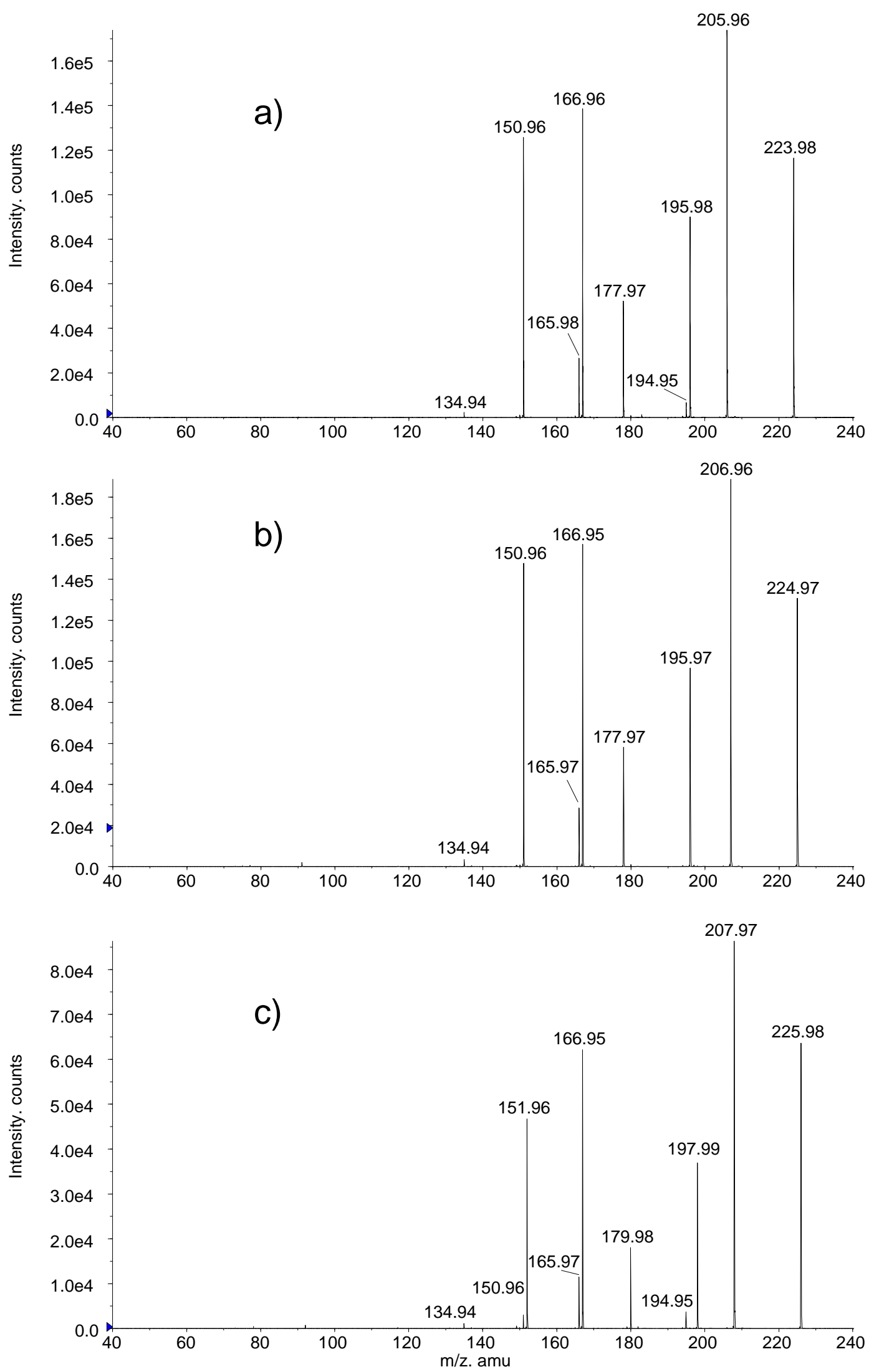

Figure 2. 


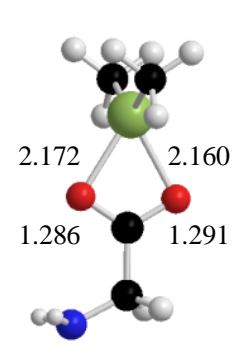

$+9.6$

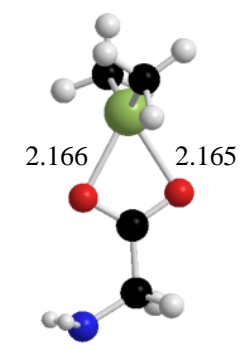

$+12.1$

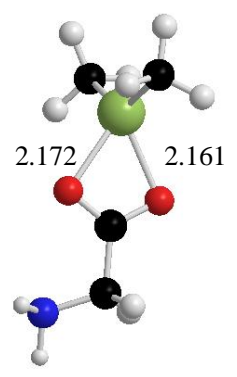

$+12.1$

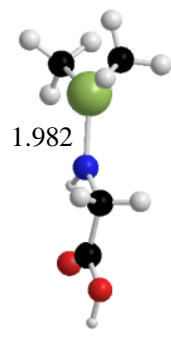

$+83.0$

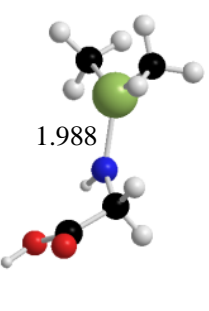

$+95.4$

DMT- $\eta^{2}-0,0-1 \quad$ DMT- $\eta^{2}-0,0-2 \quad$ DMT- $\eta^{2}-0,0-3 \quad$ DMT- $\eta^{1}-\mathrm{NH}-1 \quad$ DMT- $\eta^{1}-\mathrm{NH}-2$

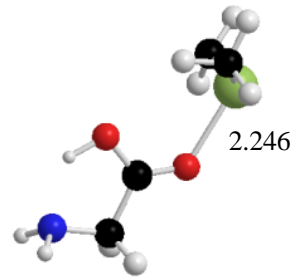

$+170.9$

DMT- $\eta^{1}-0-1$

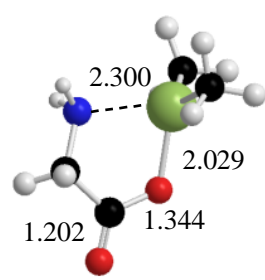

0.0

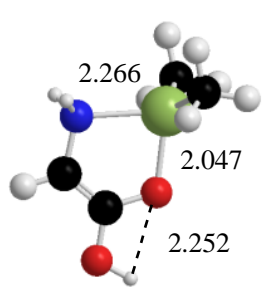

$+46.6$

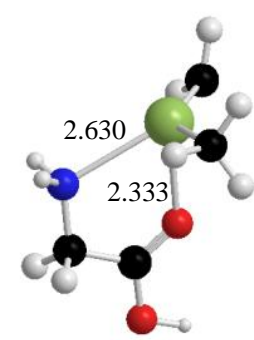

$+172.9$

DMT- $\eta^{2}-\mathrm{O}, \mathrm{NH2-1}$ DMT- $\eta^{2}-\mathrm{O}, \mathrm{NH2}-2$

DMT- $\eta^{2}-\mathbf{O}, \mathrm{NH} 2-3$

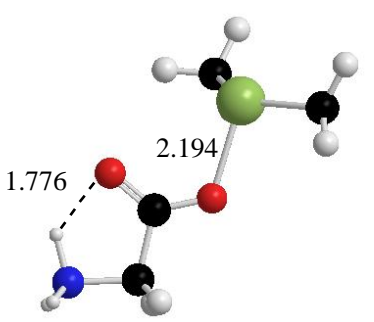

$+163.3$

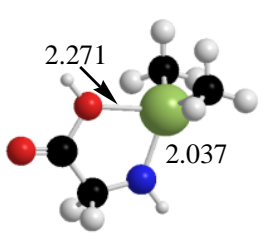

$+83.4$

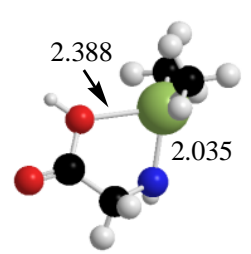

$+79.5$

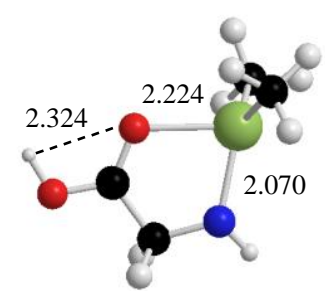

$+14.5$

DMT- $\eta^{1}-0-2$

DMT- $\eta^{2}-\mathrm{NH}, \mathrm{OH}-1$

DMT- $\eta^{2}-\mathrm{NH}, \mathrm{OH}-2$

DMT- $\eta^{2}$-NH,O-1

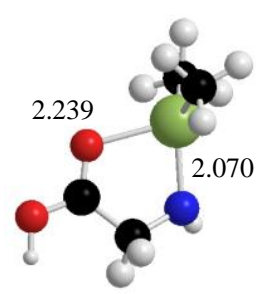

$+32.2$

DMT- $\eta^{2}-\mathrm{NH}, \mathrm{O}-2$

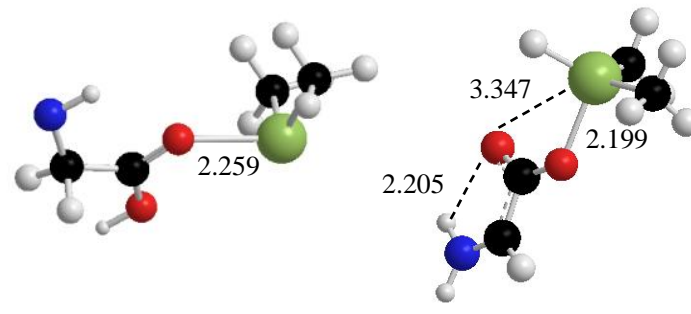

$+57.2$

INT1

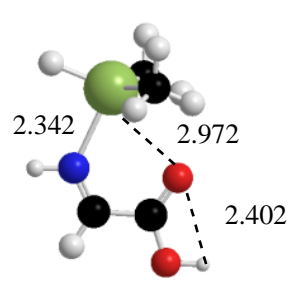

$+64.8$

INT2

Figure 3. 


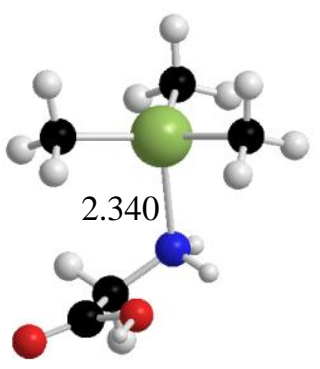

$+38.4$

TMT- ${ }^{1}$-NH2-1

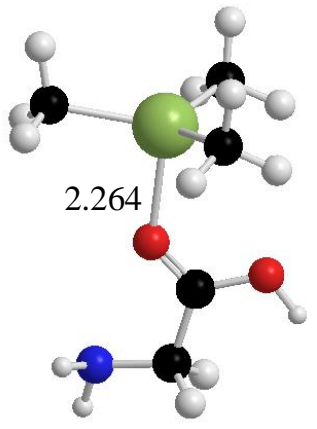

$+52.0$

TMT- $\eta^{1}-0-1$

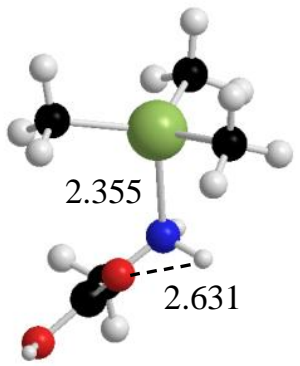

$+19.7$

TMT- ${ }^{1}$-NH2-2

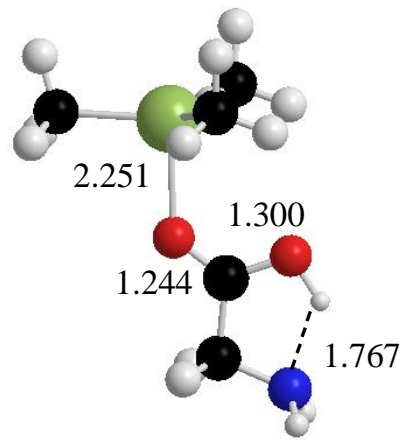

$+0.7$

TMT- $\eta^{1}-0-2$

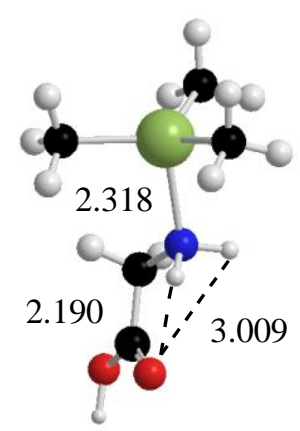

$+22.3$

TMT- $\boldsymbol{\eta}^{1}$-NH2-3

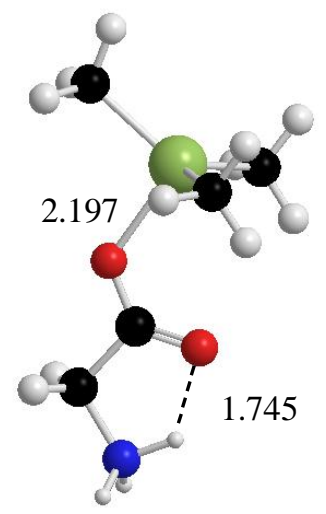

0

TMT- $\eta^{1}-Z W-1$

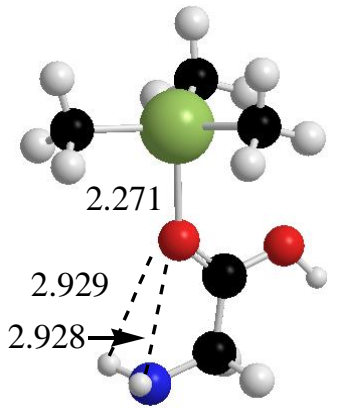

$+51.2$

TMT- $\eta^{1}-0-3$

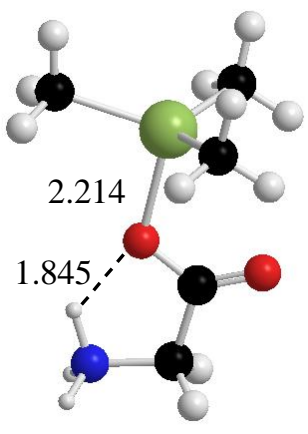

$+20.7$

TMT- $\eta^{1}-Z W-2$

Figure 4. 


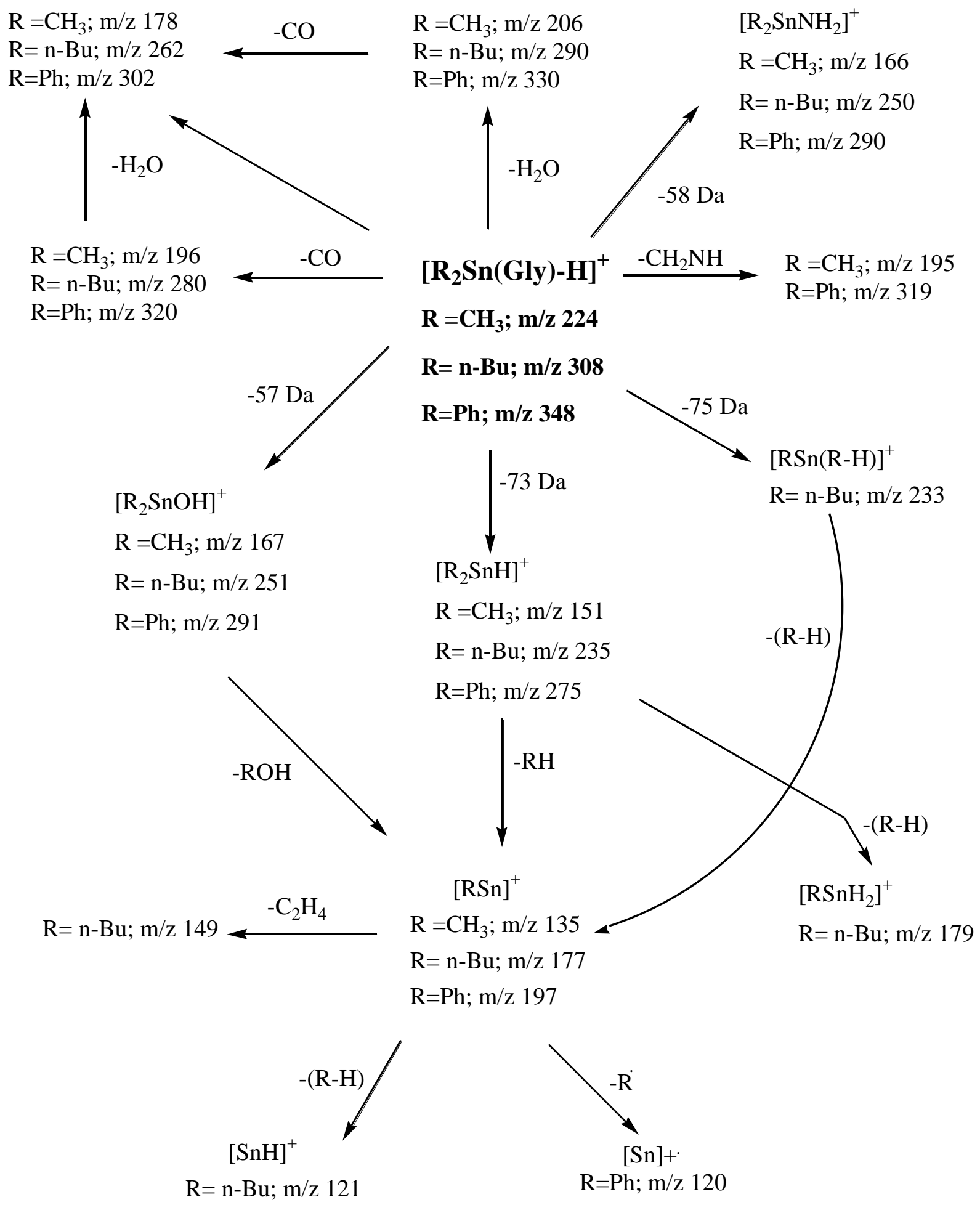

Scheme 1. 

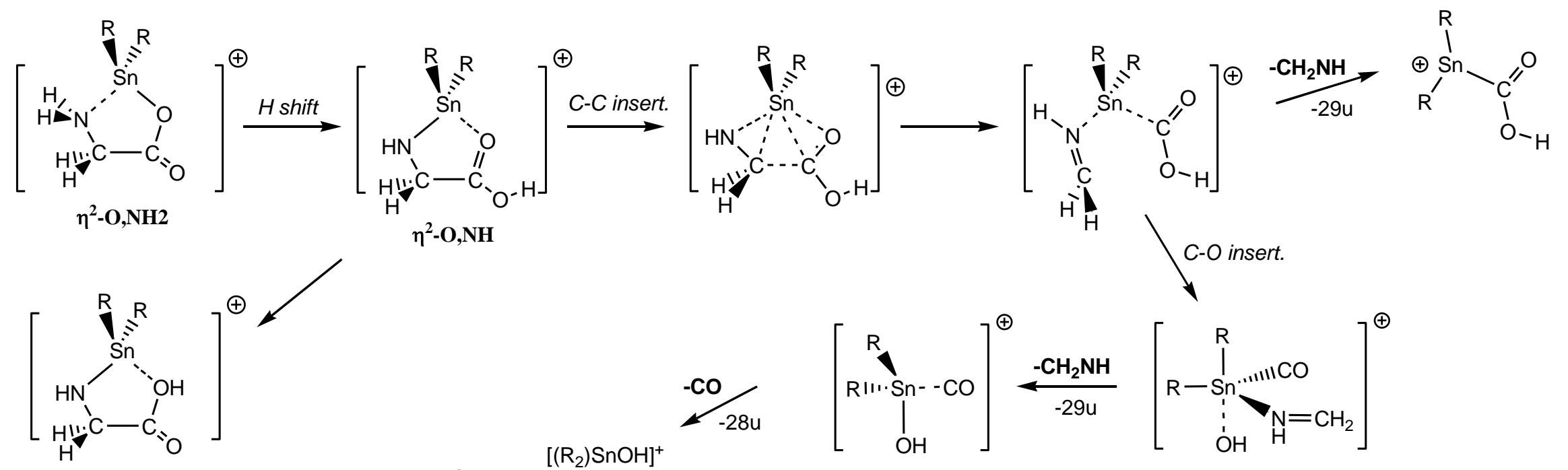

$\eta^{2}$-NH,OH

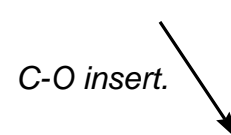

$\left[\left(\mathrm{R}_{2}\right) \mathrm{SnOH}\right]^{+}$

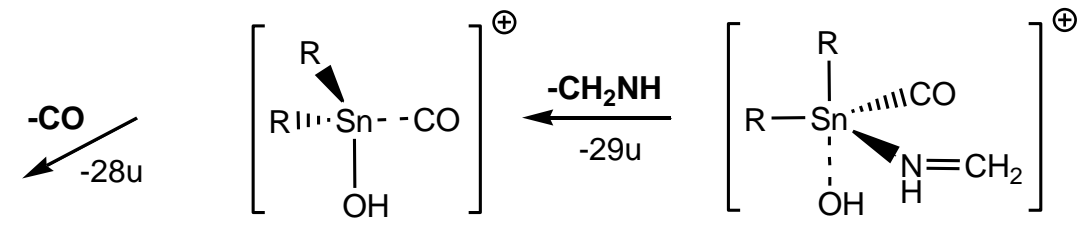

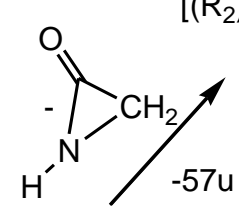

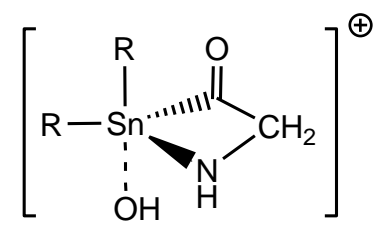

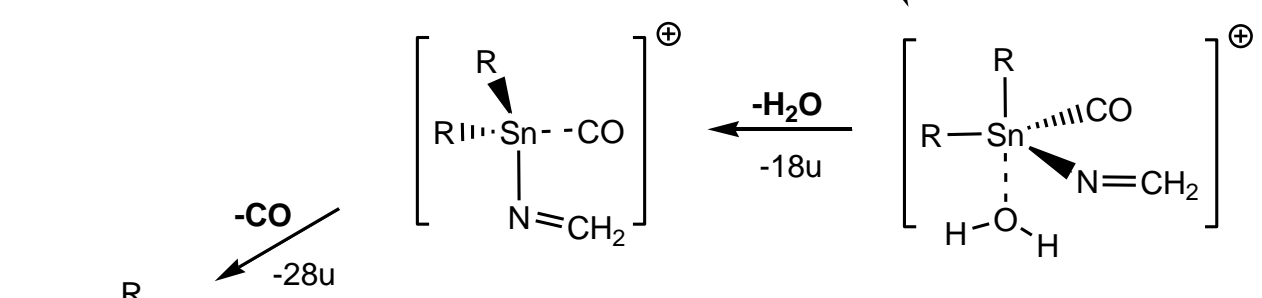

Scheme 2.

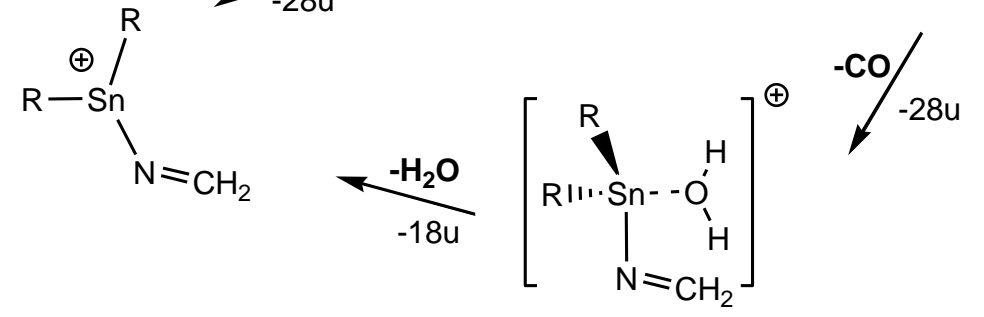




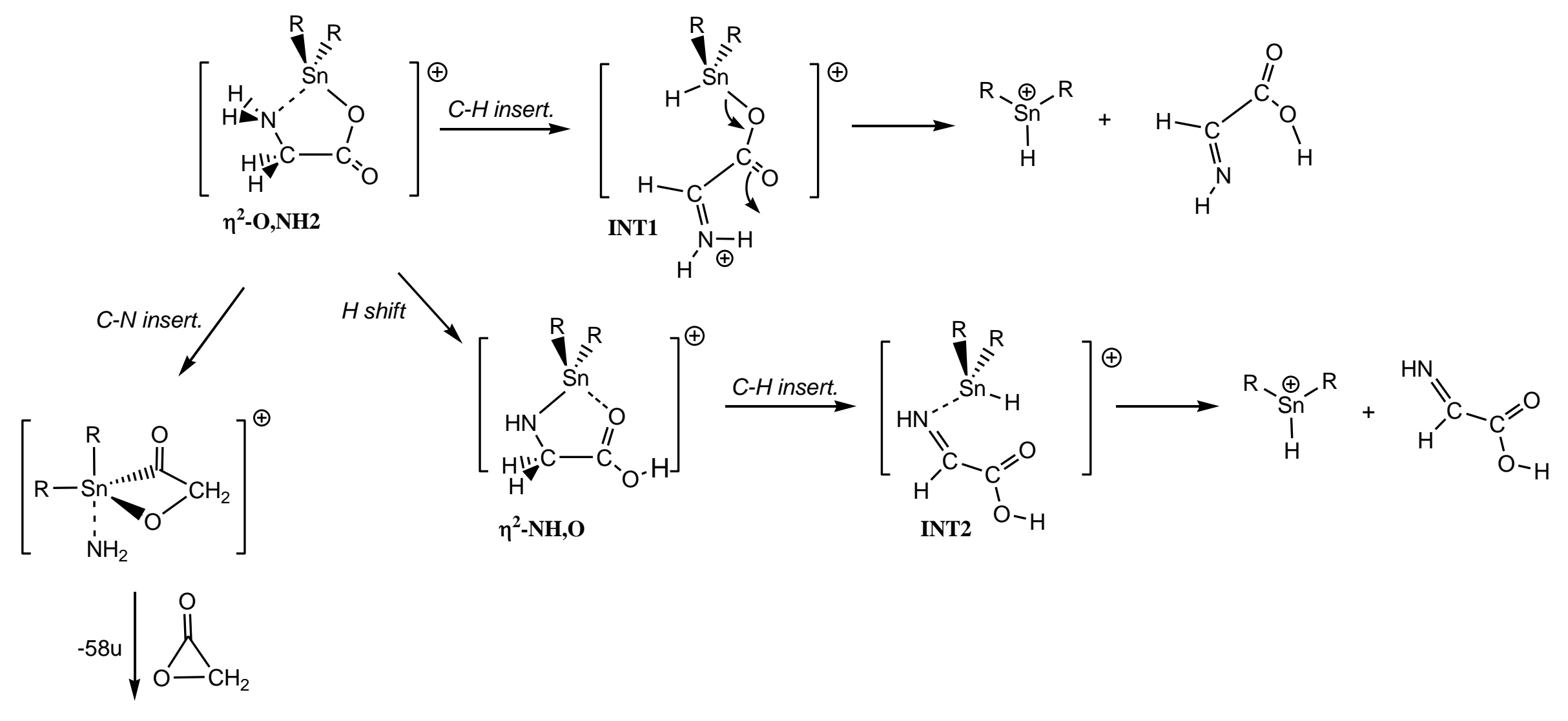

$\left[\left(\mathrm{R}_{2}\right) \mathrm{SnNH}_{2}\right]^{+}$

Scheme 3 
